\title{
Analyst
}

\section{Dual Chemosensor for the Rapid Detection of Mercury (II) Pollution and Biothiols}

\begin{tabular}{|r|l|}
\hline Journal: & Analyst \\
\hline Manuscript ID & Draft \\
\hline Article Type: & Paper \\
\hline Date Submitted by the & $\mathrm{n} / \mathrm{a}$ \\
\hline Complete List of Authors: & $\begin{array}{l}\text { Gholami, Mahnaz; Queensland University of Technology - QUT } \\
\text { Sonar, Prashant; Queensland University of Technology, School of } \\
\text { Chemistry, Physics and Mechanical Engineering } \\
\text { Manzhos, Sergei ; Institut national de la recherche scientifique Centre } \\
\text { Énergie Matériaux Télécommunications } \\
\text { Ayoko, Godwin; Queensland University of Technology, Chemistry, } \\
\text { Physics \& Mechanic Engineering } \\
\text { Kiriakous, Emad; Queensland University of technology, Nanotechnology } \\
\text { and molecular science Discipline }\end{array}$ \\
\hline
\end{tabular}

\section{SCHOLARONE ${ }^{\text {m }}$ \\ Manuscripts}




\section{Dual Chemosensor for the Rapid Detection of Mercury (II) Pollution and Biothiols}

Received 00th January 20xx, Accepted 00th January 20xx

DOI: $10.1039 / \times 0 \times x 00000 x$

\section{Introduction}

Azo dyes are a versatile class of synthetic organic compounds, which have many industrial applications in the textile, paper, and plastic industries. Benzothiazole azo dyes are heterocyclic compounds that have high stability against oxidation. They have strong colour shades that vary from red to blue according to the substituents attached in the dye's molecular structure. The optical properties of benzothiazole azo dyes can be tuned by introducing appropriate functional groups at selected positions of their heterocyclic ring. ${ }^{1}$ Additionally, benzothiazole azo dye derivatives have been successfully utilised in optoelectronic devices such as solar cells, nonlinear optics, liquid crystal displays, and optical data storage. ${ }^{2}$ The electron- donating properties of benzothiazole derivatives can be used effectively to form coordination complexes with various ions. ${ }^{3}$ There are few reports of the use benzothiazole azo dyes as a chemosensor

a. Queensland University of Technology(QUT), School of Chemistry, Physics and Mechanical Engineering, 2 George street QLD, 4000, Australia. E-mail: e.kiriakous@qut.edu.au

b. Centre Énergie Matériaux Télécommunications, Institute National de la Recherche Scientifique, 1650, boulevard Lionel-Boulet, Varennes QC J3X1S2 Canada.

+ Electronic Supplementary Information (ESI) available: [details of any supplementary information available should be included here]. See DOI: $10.1039 / x 0 x x 00000 x$ to detect heavy metals and amino acids via colourimetric and fluorescence spectroscopy methods in the literatures. ${ }^{4-12}$ Mercury is used in various industries. ${ }^{13}$ The heavy metal bioaccumulates through the food chain and can easily be converted by bacteria into a highly toxic methyl mercury derivative. In addition, mercury can affect human body organs through binding to the thiol groups of amino acids and proteins, thereby causing serious damage to the central nervous system, brain, kidney, and respiratory system. ${ }^{14-19}$

The US Environmental Protection Agency (EPA) and the World Health Organization (WHO) have set the maximum allowed concentration of $\mathrm{Hg}^{2+}$ in drinking water at $2 \mathrm{ppb}(10 \mathrm{nM}){ }^{20}$ The determination of $\mathrm{Hg}^{2+}$ pollution in environment is usually carried out by conventional advanced methods such as inductively coupled plasma mass spectroscopy (ICP-MS), ${ }^{21}$ atomic absorption spectroscopy (AAS), 22 high performance liquid chromatography (HPLC), ${ }^{23}$ and inductively coupled plasma-atomic emission spectrometry (ICP-AES). ${ }^{24}$ However, these methods are time-consuming, and require expensive instrumentation and complex sample preparation protocols. ${ }^{25}$, ${ }^{26}$ Therefore, there is a critical need for sensitive cehmosensors for the rapid and selective detection of $\mathrm{Hg}^{2+}$ pollution in the environment. $17,25,27$

Cys is a biothiol that plays a crucial role in biological processes. Cys deficiency can result in many diseases such as liver cirrhosis, delayed growth and muscle loss. In contrast, the high Cys 
cellular concentrations may lead to cancer, Alzheimer's, and cardiovascular diseases. ${ }^{28,} 29$ In addition, Cys is used in nutritional supplements and drug formulations to improve human health. ${ }^{30}$ Therefore, the determination of the concentration of Cys is important for the early diagnoses of diseases and human health.

Herein, we report the synthesis and characterisation of (E)-1((6-methoxybenzo[d]thiazole-2-yl)diazenyl)naphthalene-2,6diol (BAN) as a new chemosensor for the detection $\mathrm{Hg}^{2+}$ ions in water by UV-Vis and fluorescence spectroscopy. The complex formation between BAN and $\mathrm{Hg}^{2+}$ ions causes a spontaneous colour change from pink to blue that is used to quantify mercury pollution down to $2.5 \mu \mathrm{M}$ by UV-Vis. In addition, at $\mathrm{pH} 8$, the complex formation between $\mathrm{BAN}$ and $\mathrm{Hg}^{2+}$ ions turns on a fluorescence emission at $425 \mathrm{~nm}$ after excitation at $252 \mathrm{~nm}$. The fluorescence emission was highly selective towards the $\mathrm{Hg}^{2+}$ ion and allowed for its sensitive detection down to $1.8 \mathrm{ppb}$. The $\mathrm{BAN}-\mathrm{Hg}^{2+}$ complex was utilised for the detection of Cys where the thiol-containing amino acid binds preferentially to $\mathrm{Hg}^{2+}$ ions and, therefore, cause the dissociation of the BAN- $\mathrm{Hg}^{2+}$ complex. This leads to a colour change from blue to pink due to the liberation of the free pink-coloured BAN dye.

\section{Experimental section}

\subsection{Materials}

2,6-Dihydroxynaphthalen, 6-methoxy-2-aminobenzothiazol, sulphuric acid, hydrochloric acid, sodium nitrite, methanol, ethanol, acetonitrile, potassium carbonate, sodium hydroxide, $\mathrm{Hg}\left(\mathrm{NO}_{3}\right)_{2} . \mathrm{H}_{2} \mathrm{O}, \mathrm{NaCl}, \mathrm{Ca}\left(\mathrm{NO}_{3}\right)_{2} .4 \mathrm{H}_{2} \mathrm{O}, \mathrm{FeSO}_{4} .7 \mathrm{H}_{2} \mathrm{O}, \mathrm{Al}\left(\mathrm{NO}_{3}\right)_{3}$. $9 \mathrm{H}_{2} \mathrm{O}, \mathrm{Ni}\left(\mathrm{NO}_{3}\right)_{2} .6 \mathrm{H}_{2} \mathrm{O},\left(\mathrm{CH}_{3} \mathrm{COO}\right)_{2} \mathrm{Mn} .4 \mathrm{H}_{2} \mathrm{O}, \mathrm{CuCl}_{2}, \mathrm{ZnSO}_{4} .7 \mathrm{H}_{2} \mathrm{O}$, $\mathrm{Cd}\left(\mathrm{NO}_{3}\right)_{2} .4 \mathrm{H}_{2} \mathrm{O}, \mathrm{Pb}\left(\mathrm{NO}_{3}\right)_{2}, \mathrm{CrO}_{3}, \mathrm{KCl}, \mathrm{MgCl}_{2}$, cysteine (Cys), phenylalanine (Phe), tyrosine (Tyr), and glycine (Gln) were purchased from Sigma Aldrich and used without further purification. Deionized water was used for the preparation of aqueous solutions of various metal ions and amino acids.

\subsection{Instrumentation}

FT-IR spectra were recorded using alpha-p FTIR spectrometer with ATR accessory $\left(500-4000 \mathrm{~cm}^{-1}\right) .{ }^{1} \mathrm{H}$ and ${ }^{13} \mathrm{C}$ NMR were performed in DMSO- $d_{6}$ using a Bruker $600 \mathrm{MHz}$ NMR spectrometer and tetramethylsilane (TMS) as the internal standard. Mass spectroscopy was carried out on a LTQ XL Ion Trap instrument. Varian Cary 60 and Eclipse spectrophotometers recorded UV-Vis absorption and fluorescence emission spectra. Differential scanning calorimetry (DSC) was carried out under nitrogen using a Chimaera instrument Q100. Thermal gravimetric analysis (TGA) was carried out using Pegasus Q500TGA analyser under nitrogen atmosphere and a heating rate of $10^{\circ} \mathrm{C}$ per min.

\subsection{Synthesis and characterization of BAN}

6-Methoxy-2-aminobenzothiazole $(0.322 \mathrm{~g}, 2 \mathrm{mmol})$ was dissolved in $\mathrm{H}_{2} \mathrm{SO}_{4}(50 \%, 10 \mathrm{~mL})$ and placed in an ice bath (-5 to $\left.0{ }^{\circ} \mathrm{C}\right)$. An aqueous solution of $\mathrm{NaNO}_{2}(0.296 \mathrm{~g}, 4.3 \mathrm{mmol}$ in $3 \mathrm{~mL}$
$\mathrm{H}_{2} \mathrm{O}$ ) was added dropwise with continuous stirring for $15 \mathrm{~min}$. The resulting yellow diazonium salt was stirred between -5 to 0 ${ }^{\circ} \mathrm{C}$ for 1 hour. 2,6-Dihydroxynaphthalene $(0.36 \mathrm{~g}, 2 \mathrm{mmol})$ was dissolved in $\mathrm{NaOH}(10 \% \mathrm{wt}, 10 \mathrm{~mL}$ ) at temperature between -5 to $0^{\circ} \mathrm{C}$. The 2, 6-dihydroxynaphthalene solution was then added dropwise to the diazonium salt solution with continuous stirring in an ice bath $\left(-5\right.$ to $\left.0^{\circ} \mathrm{C}\right)$ for 1 hour until the formation of a dark purple precipitate. Finally, the reaction mixture was neutralised to $\mathrm{pH} 6$ by adding a saturated solution of potassium carbonate $\left(\mathrm{K}_{2} \mathrm{CO}_{3}\right)$. The purple product was filtered and washed several times with distilled water and methanol and recrystallised in absolute ethanol. The weight of the purified dry purple powder was $652 \mathrm{mg}(1.8 \mathrm{mmol})$ and the reaction yield 93\%. (E)-1-((6methoxybenzo[d]thiazole-2-yl)diazenyl)naphthalene-2,6-diol (BAN). ${ }^{1} \mathrm{H}$ NMR (600 MHz, DMSO-d 6 ) $\delta$ (ppm): $3.85(\mathrm{~s}, 3 \mathrm{H}), 6.83$ (d, $J=9.5 \mathrm{~Hz}, 1 \mathrm{H}$ ), 7.10 (dd, J=8.9, 2.6 Hz, 2H), 7.15 (dd, $J=8.8,2.6$ $\mathrm{Hz}, 1 \mathrm{H}), 7.64(\mathrm{~d}, J=2.6 \mathrm{~Hz}, 1 \mathrm{H}), 7.77(\mathrm{~d}, J=8.9 \mathrm{~Hz}, 1 \mathrm{H}), 7.91(\mathrm{~d}, J$ $=9.5 \mathrm{~Hz}, 1 \mathrm{H}), 8.18(\mathrm{~d}, J=8.8 \mathrm{~Hz}, 1 \mathrm{H}), 10.03(\mathrm{~s}, 1 \mathrm{H}), 15.15(\mathrm{~s}, 1 \mathrm{H}) .{ }^{13} \mathrm{C}$ NMR (151 MHz, DMSO-d 6 ) $\delta$ (ppm): 55.17, 105.09, 112.89, $114.89,118.77,122.30,123.19,123.66,129.52$, 130.96, 133.14, $142.18,145.33,156.53,156.81,165.75,171.56,205.88$. HRMS $[\mathrm{M}+\mathrm{H}]^{+} \mathrm{m} / \mathrm{z}$ calcd for $\left(\mathrm{C}_{18} \mathrm{H}_{13} \mathrm{~N}_{3} \mathrm{O}_{3} \mathrm{~S}\right) 352.07$ found 352.07 .

\subsection{Stock solutions}

A stock solution of the synthesised BAN $(0.1 \mathrm{mM})$, was prepared by dissolving the appropriate amount of the dye in acetonitrile: water mixture ( $\left.\mathrm{ACN}: \mathrm{H}_{2} \mathrm{O}, 1: 1, \mathrm{v} / \mathrm{v}\right)$. $\mathrm{HCL}(1 \mathrm{mM})$ was used to adjust the $\mathrm{pH}$ of the dye solution between 2 and 6 . $\mathrm{NaOH}$ solution ( $1 \mathrm{mM})$, was used to adjust the $\mathrm{pH}$ of the dye solution between 6 and 12. Stock solutions of $\mathrm{Hg}\left(\mathrm{NO}_{3}\right)_{2} . \mathrm{H}_{2} \mathrm{O}, \mathrm{NaCl}$, $\mathrm{Ca}\left(\mathrm{NO}_{3}\right)_{2} .4 \mathrm{H}_{2} \mathrm{O}, \mathrm{FeSO}_{4} .7 \mathrm{H} 2 \mathrm{O}, \mathrm{Al}\left(\mathrm{NO}_{3}\right)_{3} .9 \mathrm{H}_{2} \mathrm{O}, \mathrm{Ni}\left(\mathrm{NO}_{3}\right)_{2} .6 \mathrm{H}_{2} \mathrm{O}$, $\left(\mathrm{CH}_{3} \mathrm{COO}\right)_{2} \mathrm{Mn} \cdot 4 \mathrm{H}_{2} \mathrm{O}, \mathrm{CuCl}_{2}, \mathrm{ZnSO}_{4} \cdot 7 \mathrm{H}_{2} \mathrm{O}, \mathrm{Cd}\left(\mathrm{NO}_{3}\right)_{2} .4 \mathrm{H}_{2} \mathrm{O}$, $\mathrm{Pb}\left(\mathrm{NO}_{3}\right)_{2}, \mathrm{CrO}_{3}, \mathrm{KCl}, \mathrm{MgCl}_{2}(1 \mathrm{mM}), \mathrm{Cys}$, phenylalanine, tyrosine and glycine $(0.1 \mathrm{mM})$ were prepared by dissolving appropriate masses of the compounds in $10 \mathrm{~mL}$ of deionised water.

\subsection{Complex formation, UV-Vis and fluorescence measurements}

To study the complex formation between the BAN and $\mathrm{Hg}^{2+}$, aliquots of stock $\mathrm{Hg}^{2+}$ solution were added to $250 \mu \mathrm{L}$ of BAN (0.1 $\mathrm{mM}$, in $\left.\mathrm{ACN}: \mathrm{H}_{2} \mathrm{O}, 1: 1 \mathrm{v} / \mathrm{v}, \mathrm{pH}=8\right)$. $\mathrm{ACN}: \mathrm{H}_{2} \mathrm{O}$ solvent $(1: 1 \mathrm{v} / \mathrm{v})$ was used to complete the volume to $5 \mathrm{~mL}$. The final concentration of BAN in the mixture was $5 \mu \mathrm{M}$ and the final concentration of the $\mathrm{Hg}^{2+}$ ions ranged from $0.1 \mu \mathrm{M}$ to $10 \mu \mathrm{M}$. The colour change from pink to blue was observed by the naked eye, and UV absorption spectroscopy. UV-Vis spectra were recorded in the wavelength range $200-800 \mathrm{~nm}$. The complex formation of between BAN and $\mathrm{Hg}^{2+}$ ions was also studied by fluorescence spectroscopy where the emission spectrum of the blue BAN$\mathrm{Hg}^{2+}$ complex was measured between 400 and $600 \mathrm{~nm}$ using an excitation wavelength of $252 \mathrm{~nm}$.

\subsection{Study of $\mathrm{pH}$ effect and stoichiometry of the BAN-Hg complex}

To study the effect of $\mathrm{pH}$ on the complex formation between the BAN chemosensor and $\mathrm{Hg}^{2+}$ ions, equal volumes of $\mathrm{Hg}^{2+}$ $\left(5 \times 10^{-6} \mathrm{M}\right)$ and $\mathrm{BAN}\left(5 \times 10^{-6} \mathrm{M}\right)$ (in $\left.\mathrm{ACN}: \mathrm{H}_{2} \mathrm{O}, 1: 1 \mathrm{v} / \mathrm{v}\right)$ were mixed and the $\mathrm{pH}$ of the solution changed from 6 to 12 by adding $\mathrm{NaOH}(1 \mathrm{mM})$ dropwise. The change in the colour of BAN from pink to blue after the addition of $\mathrm{Hg}^{2+}$ ions was monitored by 
the naked eye and UV-Vis absorption spectra were acquired at different $\mathrm{pH}$ values. To determine the stoichiometry of the BAN$\mathrm{Hg}^{2+}$ complex, UV-Vis spectroscopic titration of the BAN $\left(5 \times 10^{-}\right.$ ${ }^{6} \mathrm{M}$ ) was carried by adding different concentrations of $\mathrm{Hg}^{2+}$ ions ( 0.002 to 2 molar equivalents), and adjusting the $\mathrm{pH}$ of the solution to 8 . The absorption maximum of the complex at 585 $\mathrm{nm}$ was acquired and the relationship between the absorption maximum and the dye- $\mathrm{Hg}^{2+}$ molar ratio was plotted.

\subsection{Interference study of BAN chemosensor towards $\mathbf{H g}^{2+}$ ions}

For interference studies, stock solutions of various $\left(10^{-3} \mathrm{M}\right)$ of $\mathrm{Na}^{+}, \mathrm{K}^{+}, \mathrm{Mg}^{2+}, \mathrm{Mn}^{2+}, \mathrm{Fe}^{2+}, \mathrm{Zn}^{2+}, \mathrm{Cu}^{2+}, \mathrm{Pb}^{2+}, \mathrm{Al}^{3+}, \mathrm{Cd}^{2+}, \mathrm{Ca}^{2+}, \mathrm{Ni}^{2+}$ and $\mathrm{Cr}^{6+}$ salts were prepared in deionised water. $500 \mu \mathrm{L}$ of the BAN $\left(10^{-4} \mathrm{M}\right.$ in ACN: $\left.\mathrm{H}_{2} \mathrm{O}, 1: 1 \mathrm{v} / \mathrm{v}, \mathrm{pH}=8\right)$ was mixed with five molar equivalents of the metal ion solution to the total volume of $5 \mathrm{~mL}$. The UV-Vis adsorption and fluorescence emission spectra of the dye/metal ion mixtures were recorded in the wavelength range $200-800 \mathrm{~nm}$ and $400-600 \mathrm{~nm}$ respectively.

\subsection{Density functional theory (DFT) simulations}

Density functional theory (DFT) simulations were performed on the BAN molecules in protonated and deprotonated (single and double deprotonated, designated as $\mathrm{BAN}-\mathrm{H}$ and $\mathrm{BAN}-2 \mathrm{H}$ respectively) forms as well as their complexes with $\mathrm{Hg}^{2+} .31,32$ The wb97xd functional ${ }^{33}$ and Lanl2dz basis ${ }^{34,35}$ set were used. The polarised continuum model (PCM) ${ }^{36}$ of the water solvent was used. Spin-restricted calculations of appropriately charged singlet systems (BAN, BAN-H ${ }^{-}, \mathrm{BAN}-2 \mathrm{H}^{2-}, \mathrm{Hg}^{2+}, \mathrm{Hg}-\mathrm{BAN}^{2+},[\mathrm{Hg}-$ BAN-H $]^{+}, \mathrm{Hg}-\mathrm{BAN}-2 \mathrm{H}, \mathrm{Hg}-\mathrm{BAN}_{2}{ }^{2+}, \mathrm{Hg}-(\mathrm{BAN}-\mathrm{H})_{2},\left[\mathrm{Hg}-(\mathrm{BAN}-2 \mathrm{H})_{2}\right]^{2-}$ were performed. Optical absorption spectra are computed with time-dependent DFT (TD-DFT) ${ }^{37}$ considering six lowest singlet excited states in complexes involving one BAN unit and twelve in complexes with two BAN units. The calculations were performed in Gaussian 09.38

\subsection{Detection of Cys by BAN-Hg ${ }^{2+}$ complex}

To detect $\mathrm{Cys}$ by the BAN- $\mathrm{Hg}^{2+}$ complex, a $10^{-5} \mathrm{M}$ stock solution of the complex was prepared by mixing $1000 \mu \mathrm{L}$ of BAN $\left(10^{-4} \mathrm{M}\right.$ in $\left.\mathrm{ACN}: \mathrm{H}_{2} \mathrm{O}, 1: 1 \mathrm{v} / \mathrm{v}\right)$ with $500 \mu \mathrm{L}$ of $\mathrm{Hg}$ (II) ions $\left(10^{-4} \mathrm{M}\right)$ and adjusting the $\mathrm{pH}$ to 8 in the final volume of $5 \mathrm{~mL}$. Aliquots of $10^{-4}$ $\mathrm{M}$ Cys aqueous solution were mixed with $250 \mu \mathrm{L}$ aliquots of the BAN- $-\mathrm{Hg}^{2+}$ complex $\left(10^{-5} \mathrm{M}\right)$ and the volume of the mixture was completed to $500 \mu \mathrm{L}$ by adding $A C N$ : $\mathrm{H}_{2} \mathrm{O}$ solvent $(1: 1 \mathrm{v} / \mathrm{v})$. The final concentration of the Cys amino acid in the prepared mixtures was in the range $0.5 \mu \mathrm{M}$ to $20 \mu \mathrm{M}$ while that of the BAN- $\mathrm{Hg}^{2+}$ complex was kept constant at $5 \mu \mathrm{M}$. The colour change from blue to pink was observed by the naked eye, and UV absorption spectroscopy. UV- Vis spectra were recorded in the wavelength range $200-800 \mathrm{~nm}$.

\subsection{Stoichiometry of cys detection by the BAN- $\mathrm{Hg}^{2+}$ complex}

To study the stoichiometry of Cys detection by the BAN- $\mathrm{Hg}^{2+}$ complex, a UV-Vis spectroscopic titration of the BAN- $\mathrm{Hg}^{2+}$ complex $\left(5 \times 10^{-6} \mathrm{M}\right)$ was carried out by adding different volumes of $10^{-4} \mathrm{M}$ Cys stock solution. Therefore, the final concentration of the amino acid was in the concentration range of 0.1 to 4 molar equivalents of the $\mathrm{BAN}-\mathrm{Hg}^{2+}$ complex. The absorption maximum of BAN at $540 \mathrm{~nm}$ was acquired and plotted against the molar ratio of Cys.

\subsection{Interference study of the Cys detection by the BAN- $\mathrm{Hg}^{2+}$}

Stock solutions of Cys, Phe and Tyr and GIn $\left(10^{-4} \mathrm{M}\right)$ were prepared by dissolving appropriate amount of the amino acid in $10 \mathrm{~mL}$ of deionised water. $250 \mu \mathrm{L}$ aliquots of the BAN- $\mathrm{Hg}^{2+}$ complex $\left(10^{-5} \mathrm{M}\right)$ were mixed with $5 \times 10^{-5} \mathrm{M}$ of each amino acid solution $\left(10^{-4} \mathrm{M}\right)$ to the total volume of $500 \mu \mathrm{L}$. The UV-Vis adsorption spectra of the resulting mixtures were recorded in the wavelength range $200-800 \mathrm{~nm}$.

\subsection{Fabrication of disposable paper based sensor for Cys detection}

A Paper based sensors for the detection of Cys was prepared by loading filter paper strips $(1 \times 5 \mathrm{~cm})$ with $1 \times 10^{-5} \mathrm{M} \mathrm{BAN}-\mathrm{Hg}^{2+}$ complex and air dried. The paper sensors were stored at room temperature for future use.

\section{Results and discussion}

\subsection{Synthesis and characterization}

BAN was synthesised by the diazotation of 6-methoxy-2aminobenzothiazole and coupling with 2,6dihydroxynaphthalene (Scheme1). The structure of BAN was confirmed by ${ }^{1} \mathrm{H} N M R,{ }^{13} \mathrm{C} N M R, \mathrm{FT}-\mathrm{IR}$ and Mass spectroscopy.

The ${ }^{1} \mathrm{H}$ NMR of the synthesised dye is depicted in Fig. S1. The singlet at $3.85 \mathrm{pm}$ is attributed to the three hydrogen protons of the methoxy group. The aromatic protons appear at 6.83 and $8.18 \mathrm{ppm}$. In addition, two singlet protons appear at 10.03 and $15.15 \mathrm{ppm}$ and are attributed to the two-hydroxyl groups within the dye structure. The signal at $15.15 \mathrm{ppm}$ may be attributed to hydrazone tautomer of the BAN dye (Fig. S2). ${ }^{39}$

The ${ }^{13} \mathrm{C}$ NMR of BAN is depicted in Fig. S3. The resonance at $55.17 \mathrm{ppm}$ is attributed to the carbon atom of the methoxy group. The 17 aromatic carbons in the dye structure appeared between $105.09 \mathrm{ppm}$ to $205.88 \mathrm{ppm}$. The signals at $171.56 \mathrm{ppm}$ and $205.88 \mathrm{ppm}$ may be attributed to the C-O bond of the hydroxyl group and the azo-hydrazone tautomer of the dye, respectively. All assigned proton and carbon peaks appeared in NMR data are matching with the chemical structure of BAN. The peak at $1464 \mathrm{~cm}^{-1}$ is attributed to the $\mathrm{N}=\mathrm{N}$ vibration in the azo form of the dye. ${ }^{40}$

The $\mathrm{C}=\mathrm{N}$ in the hydrazone form of $\mathrm{BAN}$ is also identified in the $1600 \mathrm{~cm}^{-1}$ area. The peak at $1538 \mathrm{~cm}^{-1}$ is assigned to $\mathrm{C}-\mathrm{N}$ stretch at the benzothiazole ring in BAN.
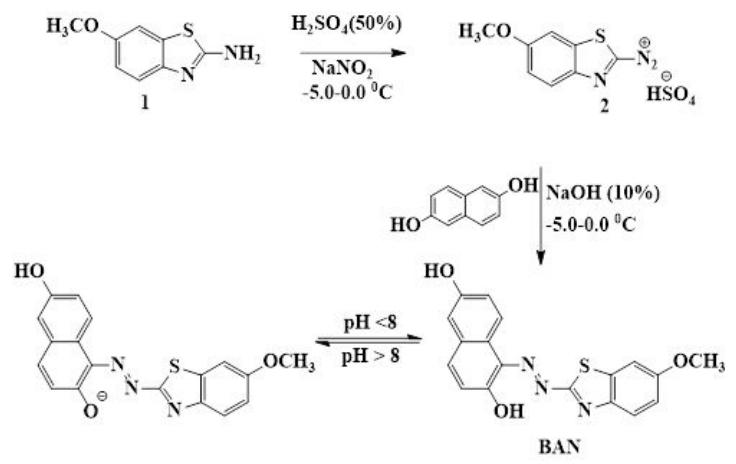

Scheme. 1 Synthesis of (E)-1-((6-methoxybenzo[d]thiazole-2yl)diazenyl)naphthalene-2,6-diol (BAN). 
The mass fragmentation pattern of BAN is depicted in Fig. S5 and shows peaks at 352.07 and 350.07 that are assigned to the $[\mathrm{M}+\mathrm{H}]$ and $[\mathrm{M}-\mathrm{H}]$ fragments respectively. The thermal behaviour of BAN was investigated by thermogravimetric analysis (TGA) and differential scanning calorimetry (DSC). The TGA analysis showed excellent thermal stability in nitrogen atmosphere. The decomposition temperature (Td) of BAN was $242{ }^{\circ} \mathrm{C}$ (2.5\% weight loss) (Fig. S6). The DSC analysis showed transition points at $219.7^{\circ} \mathrm{C}$ and $233.2^{\circ} \mathrm{C}$ that are attributed to the azo and hydrazone tautomers of the dye (Fig. S7).

\subsection{UV-Vis spectra of BAN at different $\mathrm{pH}$ values}

The UV-Vis absorption spectra of BAN at different $\mathrm{pH}$ values are depicted in Fig. 1 In the $\mathrm{pH}$ range 6-9, the pink-coloured dye show an absorption maximum at $540 \mathrm{~nm}$ (molar absorption coefficient $\left.=1.3 \times 10^{4} \mathrm{M}^{-1} \cdot \mathrm{cm}^{-1}\right)$ that is caused by $\pi-\pi^{*}$ electronic transitions. At $\mathrm{pH}$ values $(\mathrm{pH}=10-12)$, the colour of the dye turns blue and the absorption maximum is shifted gradually from 540 $\mathrm{nm}$ to $630 \mathrm{~nm}$ due to the complete deprotonation of the dye (Fig. 1).

\subsection{Complex formation between $\mathrm{BAN}$ and $\mathrm{Hg}^{2+}$ and effect of pH}

The formation of coordination complexes between benzothiazole azo dyes and metal ions has been demonstrated in the literature..$^{3-5}$ Therefore, BAN was utilised as a chemosensor for the detection of $\mathrm{Hg}^{2+}$ ions. The formation of a coordination complex between BAN and the $\mathrm{Hg}^{2+}$ ions in the $\mathrm{pH}$ range 2-12 was monitored by UV-Vis spectroscopy. At $\mathrm{pH}$ values less than 6.7 there was no change to the colour and the absorption band of BAN at $540 \mathrm{~nm}$. When the $\mathrm{pH}$ of the solution was increased from 6.7 to 8.0 in the presence of $\mathrm{Hg}^{2+}$ ions, a colour change from pink to blue was observed by naked eye. Also the absorption band of the dye shifted from $540 \mathrm{~nm}$ to 585 $\mathrm{nm}$ (Fig. 2a). The shift in the absorption band of BAN is attributed to the formation of a coordination complex between the dye and the metal ions. At pH values above 10 and in the presence of $\mathrm{Hg}^{2+}$ ions, the absorption band of the dye shifted gradually $630 \mathrm{~nm}$ and could not be distinguished from that of the deprotonated form of BAN (Fig. S8).

The complex formation between $\mathrm{BAN}$ and $\mathrm{Hg}^{2+}$ at $\mathrm{pH} 8$ was confirmed by fluorescence spectroscopy. BAN did not show any appreciable fluorescence in the $\mathrm{pH}$ range 2-12 after excitation using a wavelength of $252 \mathrm{~nm}$ (Fig. 2b, blue spectrum). However, when $\mathrm{Hg}^{2+}$ ions were added to the dye solution and the $\mathrm{pH}$ adjusted to 8 , a strong emission at $425 \mathrm{~nm}$ turned on using excitation wavelength of $252 \mathrm{~nm}$ (Fig. 2b, red spectrum). The emission quantum yield of the BAN chemosensor increased sharply from $\phi_{f}=0.011$ to $\phi_{f}=0.15$ after complexation with $\mathrm{Hg}^{2+}$ ions.

\subsection{DFT simulation of $\mathrm{BAN}-\mathrm{Hg}^{2+}$ complex formation}

DFT simulation was carried out to identify the complex formation between BAN and $\mathrm{Hg}^{2+}$ ions. Based on the DFT calculations, the $\mathrm{Hg}^{2+}$ cations coordinate to the neighbouring oxygen and nitrogen atoms of deprotonated BAN. The computed binding energy of $\mathrm{Hg}^{2+}$ ions to the protonated dye structure was found to be negligible. The binding of the metal ion was thermodynamically favoured to BAN as long as the hydroxyl group in the ortho position to the azo group is deprotonated. The binding energy of the metal ion to a deprotonated BAN molecule is computed to be $-0.85 \mathrm{eV}$. The bond length between the $\mathrm{Hg}^{2+}$ cation and both the $\mathrm{O}$ and $\mathrm{N}$ atoms of deprotonated BAN is $2.40 \AA$.

The DFT predicted no change in the $540 \mathrm{~nm}$ absorption band of protonated BAN when it interacts with $\mathrm{Hg}^{2+}$ ions (grey, light blue and deep blue spectra in Fig. S9). To the contrary, the computed spectra showed a red shift from $548 \mathrm{~nm}$ to $614 \mathrm{~nm}$ when the complex is formed between the $\mathrm{Hg}^{2+}$ ions and deprotonated BAN (orange and yellow spectra in Fig. S9). The predicted shift was in a good agreement with the experimental shift that was observed in the UV absorption of BAN from $540 \mathrm{~nm}$ to $585 \mathrm{~nm}$ upon complexation with $\mathrm{Hg}^{2+}$ ions at $\mathrm{pH} 8$ (Fig. 2a).

To support the DFT simulation of the $\mathrm{BAN}-\mathrm{Hg}^{2+}$ complex formation, $\mathrm{FT}-\mathrm{IR}$ spectra of $\mathrm{BAN}$ and $\mathrm{BAN}-\mathrm{Hg}^{2+}$ were acquired (Fig. S10). The FT-IR spectrum of the BAN- $\mathrm{Hg}^{2+}$ complex showed weak vibration modes between 3078 and $3376 \mathrm{~cm}^{-1}$ that are attributed to $\mathrm{OH}$ vibrations. In addition, the $\mathrm{N}=\mathrm{N}$ vibration of the azo group in the BAN- $\mathrm{Hg}^{2+}$ showed at $1380 \mathrm{~cm}^{-1}$ and was shifted from its position at $1464 \mathrm{~cm}^{-1}$ in the free dye. ${ }^{4}$ This shift is attributed to the formation of a coordination complex between the azo group of the dye and the $\mathrm{Hg}^{2+}$ ions.

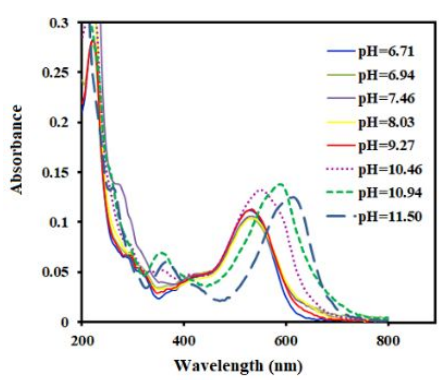

Fig. 1 UV-Vis spectra of BAN $\left(5 \times 10^{-6} \mathrm{M}\right)$ in $\mathrm{ACN}: \mathrm{H}_{2} \mathrm{O}(1: 1, \mathrm{v} / \mathrm{v})$ at different $\mathrm{pH}$ values.
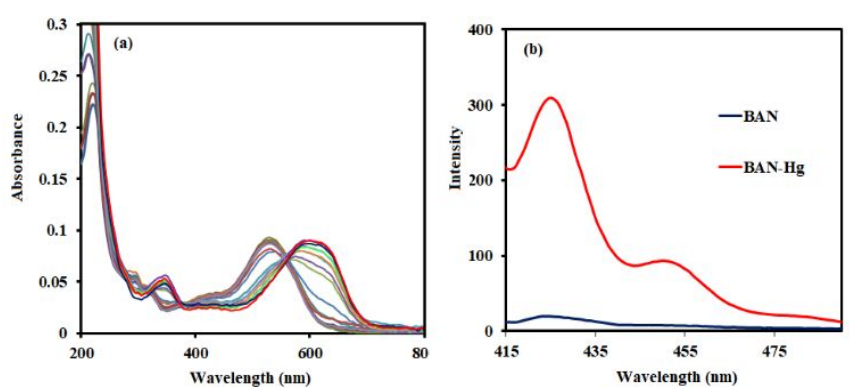

Fig. 2 (a) UV-Vis spectra of the BAN chemosensor $\left(5 \times 10^{-6} \mathrm{M}\right)$ after the addition of different volumes $\left(0-2\right.$ eq of $\left.5 \times 10^{-6} \mathrm{M}\right)$ of $\mathrm{Hg}^{2+}$ ions. (b) Fluorescence emission spectra of the BAN $\left(10^{-6} \mathrm{M}\right)$ before and after the addition of $\mathrm{Hg}^{2+}$ ions $\left(10^{-6} \mathrm{M}\right)$ and excitation at $\lambda_{\mathrm{ex}}=252 \mathrm{~nm}$. 


\subsection{Stoichiometry of the BAN-Hg ${ }^{2+}$ complex}

The concentration of BAN was kept at $5 \times 10^{-6} \mathrm{M}$ while the concentration of $\mathrm{Hg}^{2+}$ ion changed from 0 to 2 molar equivalents while maintaining the $\mathrm{pH}$ of the solution at $\mathrm{pH}$ 8. The UV-Vis spectra of the formed complexes showed an isosbestic point at $560 \mathrm{~nm}$ and an absorption band at $585 \mathrm{~nm}$, which is attributed to the formation of a BAN-Hg coordination complex. As indicated by Fig. 3a, the stoichiometry of BAN in the complex was found to be $2: 1 \mathrm{BAN}: \mathrm{Hg}^{2+}$. To rationalise this stoichiometry, we also performed DFT calculations of $\mathrm{Hg}$ complexes with two protonated or deprotonated BAN units. The binding energy to protonated BAN is insignificant. The binding energy to two deprotonated BAN units was $-1.74 \mathrm{eV}$ i.e. the 2:1 stoichiometry is indeed energetically preferred. The effects on the absorption spectra were found to be similar to the case of complexes with a single BAN unit. The energetically most stable BAN: $\mathrm{Hg}^{2+}$ complex is shown in Fig. 3b. In this complex, the $\mathrm{Hg}-\mathrm{O}$ and $\mathrm{Hg}-\mathrm{N}$ bond lengths are both around $2.41 \AA$.

\subsection{Selectivity of the BAN chemosensor towards $\mathrm{Hg}^{2+}$ ions}

To explore the chemosensor selectivity toward $\mathrm{Hg}^{2+}$ ions, the UV-Vis and fluorescence spectra of BAN were monitored after the addition of 13 different metal ions at $\mathrm{pH} 8$. As indicated by Fig. S11a, the UV-Vis spectra of the chemosensor did not change after the addition of the individual metal ions except for $\mathrm{Ni}^{2+}$, $\mathrm{Hg}^{2+}$ and $\mathrm{Cu}^{2+}$ ions which caused the absorbance of BAN dye to shift from $540 \mathrm{~nm}$ to $560 \mathrm{~nm}, 585 \mathrm{~nm}$ and $630 \mathrm{~nm}$ respectively. However, the fluorescence spectra of BAN after the addition of the metal ions did not show emission at $425 \mathrm{~nm}$ except in the presence of $\mathrm{Hg}^{2+}$ ions (Fig. S11b). Therefore, the detection of $\mathrm{Hg}^{2+}$ ions by fluorescence spectroscopy was highly selective.

\subsection{Quantification $\mathrm{Hg}^{2+}$ by $\mathrm{UV}-\mathrm{Vis}$ and fluorescence spectroscopy}

For the determination of $\mathrm{Hg}^{2+}$ in water and UV-Vis spectroscopy using BAN, the absorption band of BAN: $\mathrm{Hg}^{2+}$ complex at $585 \mathrm{~nm}$ was monitored against the concentration of the metal ion. A linear relationship between the UV absorbance at $585 \mathrm{~nm}$ and metal ion concentration was found within the concentration range $5 \times 10^{-5} \mathrm{M}(50 \mu \mathrm{M})$ to $1 \times 10^{-6} \mathrm{M}(1 \mu \mathrm{M})$ of $\mathrm{Hg}^{2+}$ ions and represented by the equation $y=0.0207 x+0.0264$ (correlation coefficient $R^{2}=0.996$ ). The limit of detection (LOD) was calculated using the equation $\mathrm{DL}=3 \sigma / \mathrm{K}(\sigma=$ standard deviation and $K$ is the slope of the calibration curve), and found to be $4.7 \times$ $10^{-7} \mathrm{M} .^{41-43}$ The limit of quantification (LOQ) of the UV method was identified experimentally to be $2.5 \times 10^{-6} \mathrm{M}$ (Fig. 4a).

The quantification of $\mathrm{Hg}^{2+}$ by $\mathrm{BAN}$ was also carried out by fluorescence spectroscopy. The emission band of the BAN: $\mathrm{Hg}^{2+}$ complex at $425 \mathrm{~nm}$ was monitored against the concentration of the metal ion. A linear relationship that is represented by the equation $y=0.2708 x+48.57\left(R^{2}=0.993\right)$ was found in the concentration range $1 \times 10^{-6} \mathrm{M}$ to $1 \times 10^{-8} \mathrm{M}$ (Fig. 4b). The LOD and $\mathrm{LOQ}$ of $\mathrm{Hg}^{2+}$ determination by the fluorescence spectroscopy method were $9.45 \times 10^{-9} \mathrm{M}(1.8 \mathrm{ppb})$ and $5 \times 10^{-8} \mathrm{M}(10 \mathrm{ppb})$ respectively. The LOD and LOQ of the $\mathrm{Hg}$ (II) detection by fluorescence spectroscopy was 2 orders of magnitude lower than that by the UV-Vis method. Therefore, the determination of $\mathrm{Hg}$ (II) in water using the BAN dye was carried out by fluorescence spectroscopy.

\subsection{Determination $\mathrm{Hg}^{2+}$ in water}

To demonstrate the potential of the new chemosensor for the detection of $\mathrm{Hg}^{2+}$ pollution, tap water was collected and screened by ICP-OES for $\mathrm{Hg}^{2+}$ contamination. The ICP-OES measurement confirmed the absence of the heavy metal in the water sample.

The tap water sample was then spiked with $\mathrm{Hg}^{2+}$ ions to the final concentration of $1 \times 10^{-7} \mathrm{M}$. One volume of the spiked water sample was mixed with one volume of BAN $\left(2 \times 10^{-7} \mathrm{M}\right)$, the $\mathrm{pH}$ adjusted to 8 . The final concentration of $\mathrm{Hg}^{2+}$ ions in the mixture was $5 \times 10^{-8} \mathrm{M}$. The intensity of the fluorescence emission at 425 $\mathrm{nm}$ was recorded (Fig. S12). Using the regression equation in Fig. $4 \mathrm{~b}$, the concentration of $\mathrm{Hg}^{2+}$ was determined to be $4.46 \times 10^{-8}$ $M(n=3)$ and the \% recovery was $89.2 \% \pm 3$. The detection of $\mathrm{Hg}^{2+}$ by the new chemosensor was compared to that carried out by other chemosensors (Table S1).

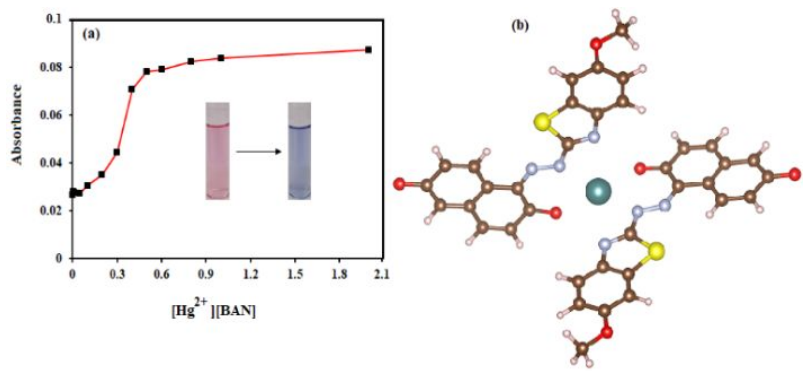

Fig. 3 (a) Change in the chemosensor UV absorbance at $585 \mathrm{~nm}$ with the concentration of $\mathrm{Hg}^{2+}$ ions. The inset shows the change in colour due to the addition of $\mathrm{Hg}^{2+}$ ions. (b) Complex between $\mathrm{Hg}^{2+}$ ions and deprotonated BAN molecules. Atom colour scheme here and elsewhere: C- brown, O- red, $\mathrm{N}$ - blue, $\mathrm{S}$ yellow, $\mathrm{H}$ - pink, and $\mathrm{Hg}$ - turquoise.
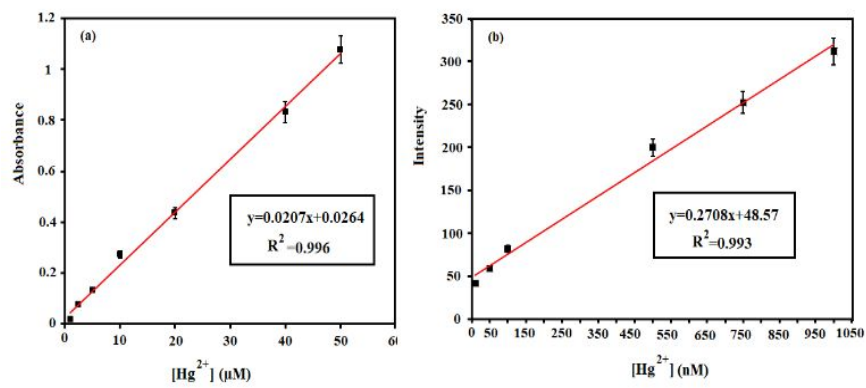

Fig. 4 (a) Linear correlation plot of absorbance at $585 \mathrm{~nm}$ versus the concentration of $\mathrm{Hg}(\mathrm{II})$ and corresponding UV-Vis spectra from $1 \times 10^{-6} \mathrm{M}$ to $5 \times 10^{-5} \mathrm{M}$. (b) A linear correlation plot of intensity of emission at $425 \mathrm{~nm}\left(\lambda_{\mathrm{ex}}=252 \mathrm{~nm}\right)$ versus the concentration of $\mathrm{Hg}(\mathrm{II})$ and the corresponding emission spectra from $1 \times 10^{-8} \mathrm{M}$ to $1 \times 10^{-6} \mathrm{M}$. 
As indicated by Table S1, the new chemosensor is very sensitive and can detect $1.8 \mathrm{ppb}$ of $\mathrm{Hg}^{2+}$ ions in water. The maximum allowed concentration of $\mathrm{Hg}^{2+}$ in drinking water is set by the EPA and WHO authorities at $2 \mathrm{ppb}(10 \mathrm{nM}){ }^{20}$ Therefore, the new chemosensor is satisfactory for the detection of $\mathrm{Hg}^{2+}$ pollution in drinking water.

\subsection{Detection of Cys by the $\mathrm{BAN}-\mathrm{Hg}^{2+}$ complex}

It is known that mercury has high affinity towards thiolcontaining amino acids. ${ }^{44}$ Therefore, the $\mathrm{BAN}-\mathrm{Hg}^{2+}$ complex was used to detect Cys. Upon the addition of aqueous Cys to the BAN- $\mathrm{Hg}^{2+}$ complex, a distinct colour change from blue to pink was observed by the naked eye. This was confirmed by observing the UV-Vis spectrum of the BAN- $\mathrm{Hg}^{2+}$ complex before and after the addition of Cys. As indicated by Fig. S13, the absorption band of the BAN-Hg ${ }^{2+}$ complex at $585 \mathrm{~nm}$ disappeared and that of the free BAN dye re-appeared at 540 $\mathrm{nm}$ upon the addition of Cys. The change in colour and UV-Vis absorption spectra is attributed to the formation of a Cys- $\mathrm{Hg}^{2+}$ complex and the dissociation of the $\mathrm{BAN}-\mathrm{Hg}^{2+}$ complex, thus leading to the regeneration of the pink-coloured BAN dye. ${ }^{45}$

The UV-Vis spectrum of the BAN- $\mathrm{Hg}^{2+}$ complex after the addition of Csy was monitored at 20 second time intervals after the addition of Cys (Fig. S14 a,b). As indicated by the figures, the $540 \mathrm{~nm}$ absorption band of BAN arrived to a maximum after 20 seconds. Therefore, a reaction time of 20 seconds was selected in subsequent experiments.

\subsection{Stoichiometry of the Cys- $\mathrm{Hg}^{2+}$ complex}

To determine the stoichiometry of the formed Cys- $\mathrm{Hg}^{2+}$ complex, constant volumes of the $\mathrm{BAN}-\mathrm{Hg}^{2+}$ complex solution $\left(5 \times 10^{-6} \mathrm{M}\right)$ were mixed with $0.1-4$ molar equivalents of $5 \times 10^{-6} \mathrm{M}$ Cys solution. The UV-Vis spectra of the formed complexes are depicted in Fig. 5 a and show an isosbestic point at $560 \mathrm{~nm}$ as well as the reappearance of the BAN absorption band at 540 $\mathrm{nm}$. Fig. $5 \mathrm{~b}$ indicates that the absorbance of the $540 \mathrm{~nm}$ band arrives to a maximum when the Cys: $\mathrm{BAN}-\mathrm{Hg}^{2+}$ molar ratio is $2: 1$, thus indicating the formation of a $2: 1 \mathrm{Csy}-\mathrm{Hg}^{2+}$ complex.
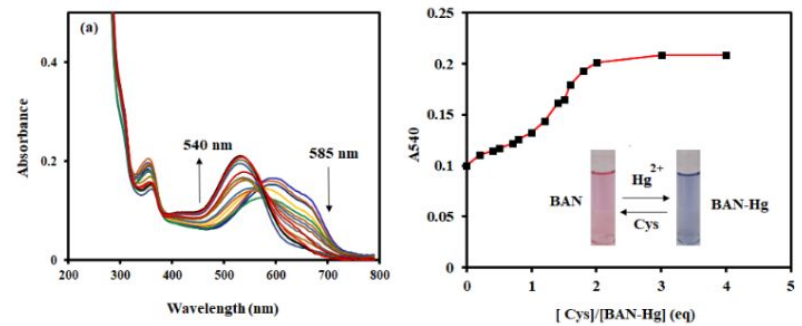

Fig. 5 (a) UV-Vis spectra of the BAN-Hg ${ }^{2+}$ complex $\left(5 \times 10^{-6} \mathrm{M}\right)$ after the addition of different volumes of Cys solution $\left(5 \times 10^{-6}\right.$ M). (b) Change in the UV absorbance of the BAN- $\mathrm{Hg}^{2+}$ complex at $540 \mathrm{~nm}$ with the concentration of Cys. The inset depicts the change in colour due to the addition of Cys solution.

\subsection{Selectivity of the BAN-Hg ${ }^{2+}$ complex towards Cys}

Selectivity study of BAN-Hg chemosensor to Cys over other 3 various natural amino acids including Tyr, Phe and Gln were conducted.

To determine the selectivity of the BAN- $\mathrm{Hg}^{2+}$ complex towards biothiols over non-thiol-containing amino acids, it was interacted with Cys, Phe, Tyr and GIn respectively. As shown in Fig. $6 \mathrm{a}$, the colour of the BAN- $\mathrm{Hg}^{2+}$ complex changed from blue to pink and its UV-Vis absorption shifted to $540 \mathrm{~nm}$ when Cys was added while no obvious changes took place with the addition of the Phe, Tyr and GIn amino acids. This result is attributed to the high affinity of the $\mathrm{Hg}$ (II) ions towards the sulfhydryl end group of Cys and the formation of a Csy- $\mathrm{Hg}^{2+}$ complex. ${ }^{45}$

\subsection{Quantification of Cys by BAN-Hg chemosensor}

For the determination of Cys by UV-Vis spectroscopy using the BAN- $\mathrm{Hg}^{2+}$ complex, the absorption band of BAN: $\mathrm{Hg}^{2+}$ complex at $585 \mathrm{~nm}$ and BAN at $540 \mathrm{~nm}$ were monitored against the concentration of the amino acid. A linear relationship between the A540/A585 absorbance ratio and Cys concentration was found within the range $1 \times 10^{-5} \mathrm{M}(10 \mu \mathrm{M})$ to $1 \times 10^{-7} \mathrm{M}(0.1 \mu \mathrm{M})$ of Cys and represented by the equation $y=0.0248 x+1.3145$ (correlation coefficient $\mathrm{R}^{2}=0.972$ ) (Fig. $6 \mathrm{~b}$ ), which is satisfactory for the detection of Cys in healthy subjects and patients with liver cirrhosis condition where the average concentration of the Cys amino acid in human blood plasma is in the range of $=$ $6.9 \pm 1.1 \mu \mathrm{M}$ to $7.8 \pm 1.0 \mu \mathrm{M}$ respectively. ${ }^{46}$

\subsection{Paper-based sensors for the rapid detection of Cys}

The rapid, sensitive and cost-effective detection of Cys in vitro and in living cells is important for human health. To utilise the $\mathrm{BAN}-\mathrm{Hg}^{2+}$ for the detection of Cys, it was loaded onto filter paper strips. The BAN- $\mathrm{Hg}^{2+}$ coated paper strips were used for the detection of the purified amino down to $5 \mu \mathrm{M}$ where the blue coloured strips turned pink colour in presence of the amino acid (Fig. 7). Therefore, the BAN-Hg ${ }^{2+}$ coated paper strips can be used as an optical sensor for the rapid screening of Cys in pharmaceutical products, and nutritional supplements.
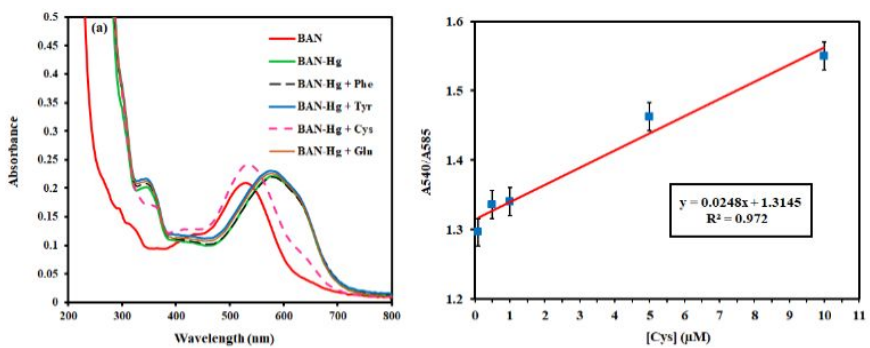

Fig. 6 (a) UV-Vis spectra of BAN-Hg $\left(5 \times 10^{-6} \mathrm{M}\right)$ after the addition of 4 amino acids $\left(2.5 \times 10^{-5} \mathrm{M}\right)$. (b) Linear correlation plot of ratio 
absorbance at $540 \mathrm{~nm}$ and $580 \mathrm{~nm}$ versus the concentration of 2 Cys and corresponding UV-Vis spectra from $1 \times 10^{-5}$ to $1 \times 10^{-7} \mathrm{M}$.

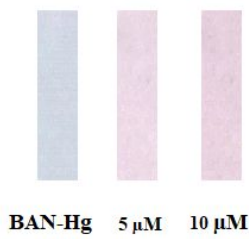

Fig. 7 Visual detection of Cys by paper-based sensor.

\section{Conclusions}

A new benzothiazole azo dye was synthesised and utilised as a chemosensor for the rapid detection of $\mathrm{Hg}^{2+}$ ions in water. The new chemosensor forms a spontaneous 2:1 coordination complex with $\mathrm{Hg}^{2+}$ ions at $\mathrm{pH}$ 8. The complex formation caused the colour of the chemosensor to change from pink to blue and turned on a strong fluorescence emission at $425 \mathrm{~nm}$. The chemosensor showed high selectivity towards $\mathrm{Hg}^{2+}$ over 13 other metal ions. The new chemosensor was utilised for monitoring $\mathrm{Hg}^{2+}$ contamination in water by fluorescence spectroscopy. The limit of detection by the fluorescence method was found to be $9.45 \times 10^{-9} \mathrm{M}(1.8 \mathrm{ppb})$ which satisfies the detection limit recommended by EPA and WHO organizations. The blue-coloured $\mathrm{BAN}-\mathrm{Hg}^{2+}$ complex was used for the rapid detection of the thiol-containing amino acid "Cys" where its colour turns back to pink due to the dissociation of the $\mathrm{BAN}-\mathrm{Hg}^{2+}$ complex and the release of the free pink-colour BAN. The described chemosensor has strong potential as a costeffective, sensitive and selective chemosensor for the detection of $\mathrm{Hg}^{2+}$ in water while its mercury complex has a strong potential as a disposable sensor for the detection of purified Cys, and other biothiols such as homocysteine and glutathione in biology research and pharmaceutical/food industries.

\section{Acknowledgements}

Mahnaz D. Gholami is thankful to Queensland University of Technology (QUT) for Postgraduate Research Award (QUTPRA) for conducting her doctoral research. The authors also acknowledge the support from the Science and Engineering Faculty to access the Central Analytical Research Facility (CARF) at QUT.

\section{References}

U. A. Hrozhyk, S. V. Serak, N. V. Tabiryan, L. Hoke, D. M. Steeves and B. R. Kimball, Opt. Express, 2010, 18, 86978704.
F. L. Coelho, C. d. Á. Braga, G. M. Zanotto, E. S. Gil, L. F. Campo, P. F. B. Gonçalves, F. S. Rodembusch and F. d. S. Santos, Sens. and Actuators, B, 2018, 259, 514-525. N. Kaur, J. Singh, G. Dhaka, R. Rani and V. Luxami, Supramol. Chem., 2015, 27, 453-459.

A. Misra and M. Shahid, J. Phys. Chem. C, 2010, 114, 1672616739.

B. K. Momidi, V. Tekuri and D. R. Trivedi, Inorg. Chem. Commun., 2016, 74, 1-5.

\section{F. Nourmohammadian, J. Anal. Chem., 2016, 71, 50-55.}

R. G. Lv, S. W. Chen and Y. Gao, Heterocycl. Commun., 2017, 23, 389-394.

G. Dhaka, N. Kaur and J. Singh, Supramol. Chem., 2015, 27, 654-660.

H. Bingol, E. Kocabas, E. Zor and A. Coskun, Talanta, 2010, 82, 1538-1542.

C. Dyrager, R. P. Vieira, S. Nyström, K. P. R. Nilsson and T. Storr, New J. Chem., 2017, 41, 1566-1573.

J. Y. Jung, S. J. Han, J. Chun, C. Lee and J. Yoon, Dyes Pigm, 2012, 94, 423-426.

S. G. a. K. Kandasamy, Biosens J., 2015, 4, 9.

T. Yu, T. T. Zhang, W. Zhao, J. J. Xu and H. Y. Chen, Talanta, 2017, 165, 570-576.

J. Xu, Z. Xu, Z. Wang, C. Liu, B. Zhu, X. Wang, K. Wang, J. Wang and G. Sang, Luminescence, 2018, 33, 219-224.

S. L. Kao, P. Venkatesan and S. P. Wu, New J. Chem., 2015, 39, 3551-3557.

T. Syversen and P. Kaur, J. Trace Elem. Med. Biol., 2012, 26, 215-226.

S. Guang, J. Tian, G. Wei, Z. Yan, H. Pan, J. Feng and H. Xu, Talanta, 2017, 170, 89-96.

T. W. Clarkson, L. Magos and G. J. Myers, N. Engl. J. Med., 2003, 349, 1731-1737.

K. Wang, X. Mao, L. Cao, G. Lv, X. Dong, Y. He and Y. Wei, J. Fluoresc., 2017, 27, 1739-1745.

Q. Wei, R. Nagi, K. Sadeghi, S. Feng, E. Yan, S. J. Ki, R. Caire, D. Tseng and A. Ozcan, ACS Nano, 2014, 8, 1121-1129.

M. M. Lynam, B. Klaue, G. J. Keeler and J. D. Blum, J. Anal. At. Spectrom., 2013, 28, 1788-1795.

O. Çaylak, Ş. G. Elçi, A. Höl, A. Akdoğan, Ü. Divrikli and L. Elçi, Food Chem., 2019, 274, 487-493.

X. Jia, Y. Han, X. Liu, T. Duan and H. Chen, Spectrochim. Acta Part B., 2011, 66, 88-92.

X. Chai, X. Chang, Z. Hu, Q. He, Z. Tu and Z. Li, Talanta, 2010, 82, 1791-1796.

X. Wang, Z. Gao, J. Zhu, Z. Gao and F. Wang, Polym. Chem., 2016, 7, 5217-5220.

Q. Mei, R. Tian, Y. Shi, Q. Hua, C. Chen and B. Tong, New. J. Chem., 2016, 40, 2333-2342.

Q.-Q. Rui, Y. Zhou, Y. Fang and C. Yao, Spectrochim. Acta Part A, 2016, 159, 209-218.

Q. Miao, Q. Li, Q. Yuan, L. Li, Z. Hai, S. Liu and G. Liang, Anal. Chem., 2015, 87, 3460-3466.

L. Brattström, A. Lindgren. B. Israelsson, A. Andersson. and B. Hijltberg, J Intern Med. 1994, 236, 633-641.

N. Clemente Plaza, M. Reig García-Galbis and R. M. Martínez-Espinosa, Molecules, 2018, 23, 575.

P. Hohenberg and W. Kohn, Phys. Rev., 1964, 136, B864B871.

W. K. a. L. J. Sham, Phys. Rev., 1965, 140, 6. J.-D. Chai and M. Head-Gordon, Phys. Chem. Chem. Phys., 2008, 10, 6615-6620. 
J. a. P. J. H. T. H. Dunning, Gaussian Basis Sets for Molecular Calculations, 1977, 3, Chapter 1. P. J. Hay and W. R. Wadt, J. Chem.Phys., 1985, 82, 270-283. J. Tomasi, B. Mennucci and R. Cammi, Chem. Rev., 2005, 105, 2999-3093. C. Adamo and D. Jacquemin, Chem. Soc. Rev., 2013, 42, 845-856.

38 G. W. T. M. J. Frisch, H. B. Schlegel, G. E. Scuseria, M. A. Robb, J. R. Cheeseman, G. Scalmani, V. Barone, G. A. Petersson, H. Nakatsuji, X. Li, M. Caricato, A. Marenich, J. Bloino, B. G. Janesko, R. Gomperts, B. Mennucci, H. P. Hratchian, J. V. Ortiz, A. F. Izmaylov, J. L. Sonnenberg, D. Williams-Young, F. Ding, F. Lipparini, F. Egidi, J. Goings, B. Peng, A. Petrone, T. Henderson, D. Ranasinghe, V. G. Zakrzewski, J. Gao, N. Rega, G. Zheng, W. Liang, M. Hada, M. Ehara, K. Toyota, R. Fukuda, J. Hasegawa, M. Ishida, T. Nakajima, Y. Honda, O. Kitao, H. Nakai, T. Vreven, K. Throssell, J. A. Montgomery, Jr., J. E. Peralta, F. Ogliaro, M. Bearpark, J. J. Heyd, E. Brothers, K. N. Kudin, V. N. Staroverov, T. Keith, R. Kobayashi, J. Normand, K. Raghavachari, A. Rendell, J. C. Burant, S. S. Iyengar, J. Tomasi, M. Cossi, J. M. Millam, M. Klene, C. Adamo, R. Cammi, J. W. Ochterski, R. L. Martin, K. Morokuma, O. Farkas, J. B. Foresman, and D. J. Fox., Gaussian 09, 2016, Revision E.01.

39 G. Pavlović, L. Racané, H. Čičak and V. Tralić-Kulenović, Dyes Pigm., 2009, 83, 354-362.

40 A. Tupys, J. Kalembkiewicz, Y. Bazel, L. Zapała, M. Dranka, Y. Ostapiuk, O. Tymoshuk and E. Woźnicka, J. Mol. Struct., 2017, 1127, 722-733.

41 C. Arivazhagan, R. Borthakur and S. Ghosh, Organometallics, 2015, 34, 1147-1155.

42 J. Liu and Y. Qian, J. Lumin., 2017, 187, 33-39.

43 Y. Mao, M. Hong, A. Liu and D. Xu, J. Fluoresc., 2015, 25, 755-761.

44 H. A. Spiller, Clin. Toxicol, 2018, 56, 313-326.

45 D. Chen, S. Lei and Y. Chen, Sensors, 2011, 11, 6509-6516.

46 R. K. Chawla, F. W. Lewis, M. H. Kutner, D. M. Bate, R. G. B. Roy and D. Rudman, Gastroenterology, 1984, 87, 770-776. 


\section{Supporting Information}

\section{Dual Chemosensor for the Rapid Detection of Mercury (II) Pollution and Biothiols}

Mahnaz D.Gholami ${ }^{a}$, Sergei Manzhos ${ }^{b}$, Prashant Sonar ${ }^{a}$, Godwin A. Ayoko ${ }^{a}$, Emad L. Izake ${ }^{\text {** }}$

${ }^{a}$ Queensland University of Technology(QUT), School of Chemistry, Physics and Mechanical Engineering, 2 George street QLD, 4000, Australia

b Centre Énergie Matériaux Télécommunications, Institute National de la Recherche Scientifique, 1650, boulevard Lionel-Boulet, Varennes QC J3X1S2 Canada.

*Corresponding author e-mail: e.kiriakous@qut.edu.au

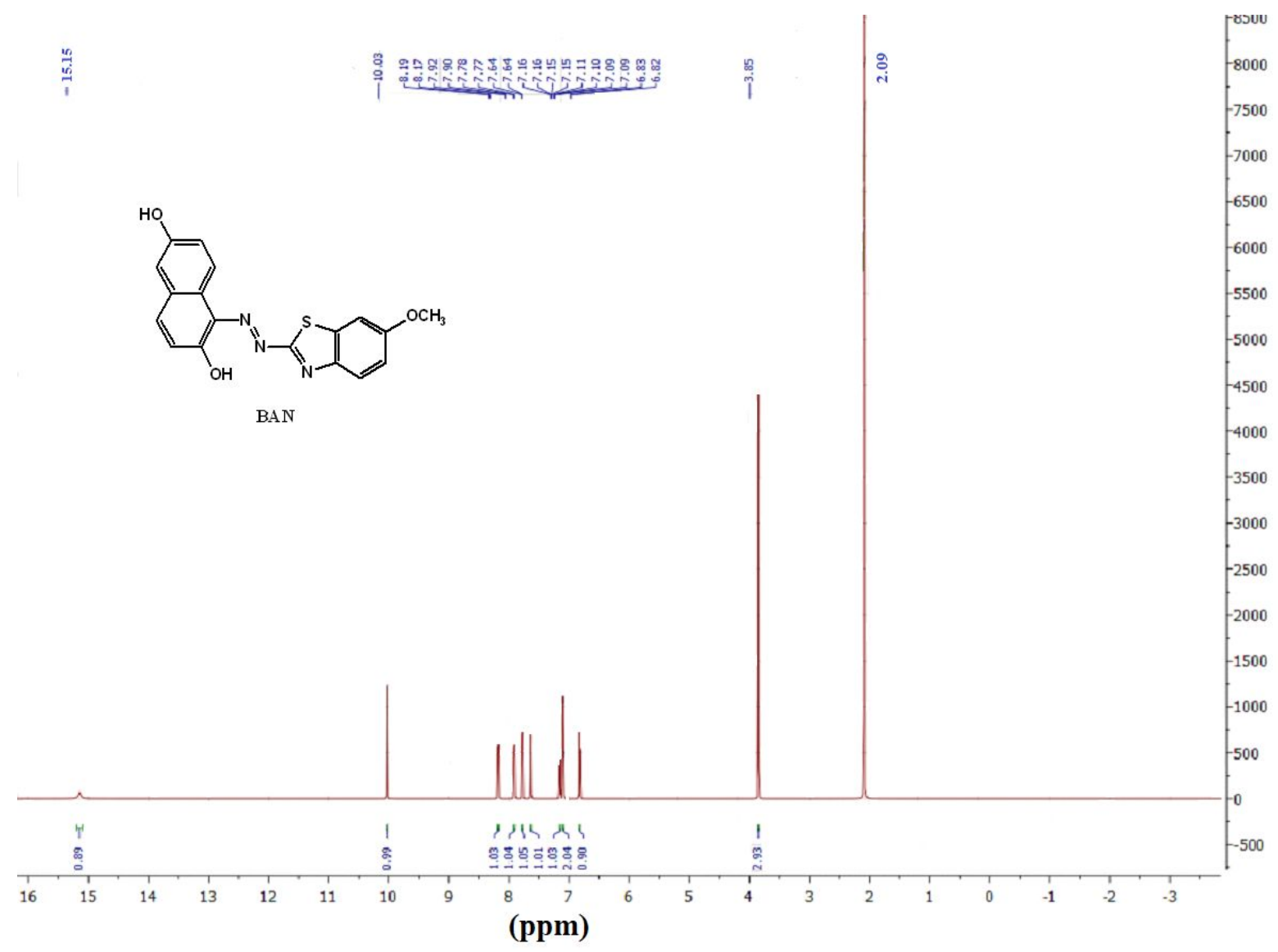

Fig. S1. ${ }^{1} \mathrm{H}$ NMR (600 MHz, DMSO-d 6 ) spectrum of BAN. 
<smiles></smiles>

Fig. S2. Azo-hydrazone tautomerism of BAN.

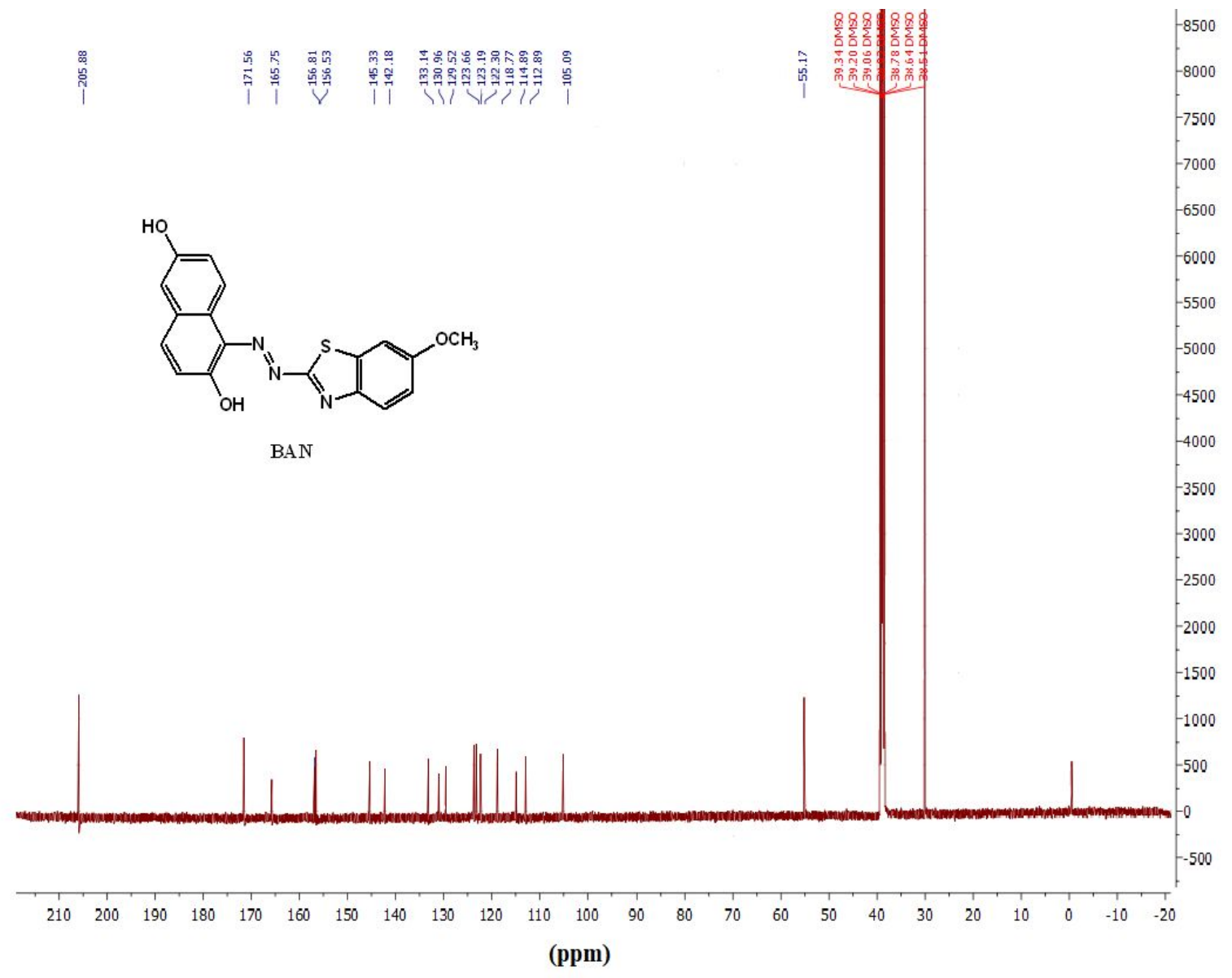

Fig. S3. ${ }^{13} \mathrm{C}$ NMR $\left(151 \mathrm{MHz}, \mathrm{DMSO}-\mathrm{d}_{6}\right)$ spectrum of BAN. 


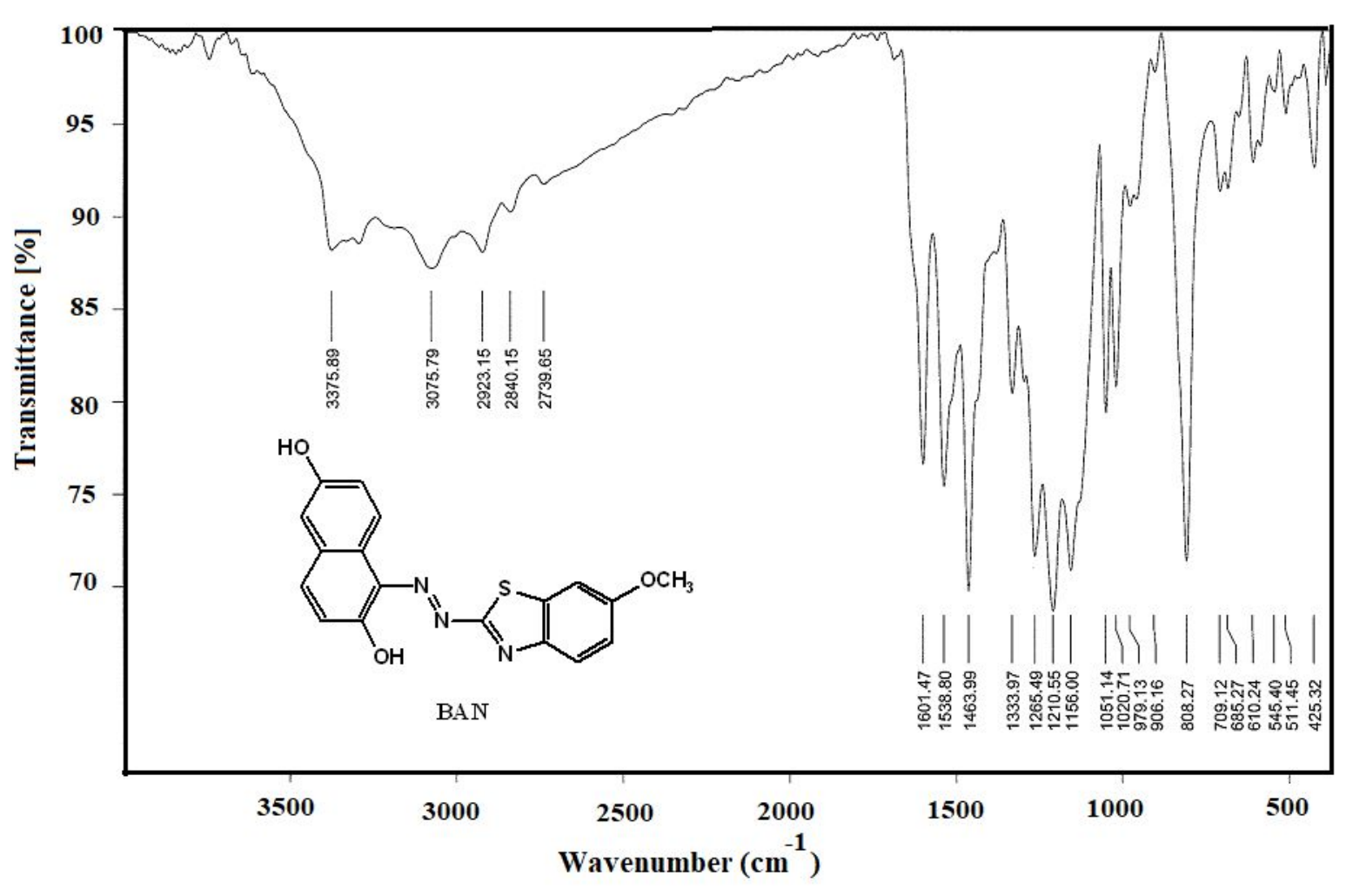

Fig. S4. FTIR spectrum of BAN.

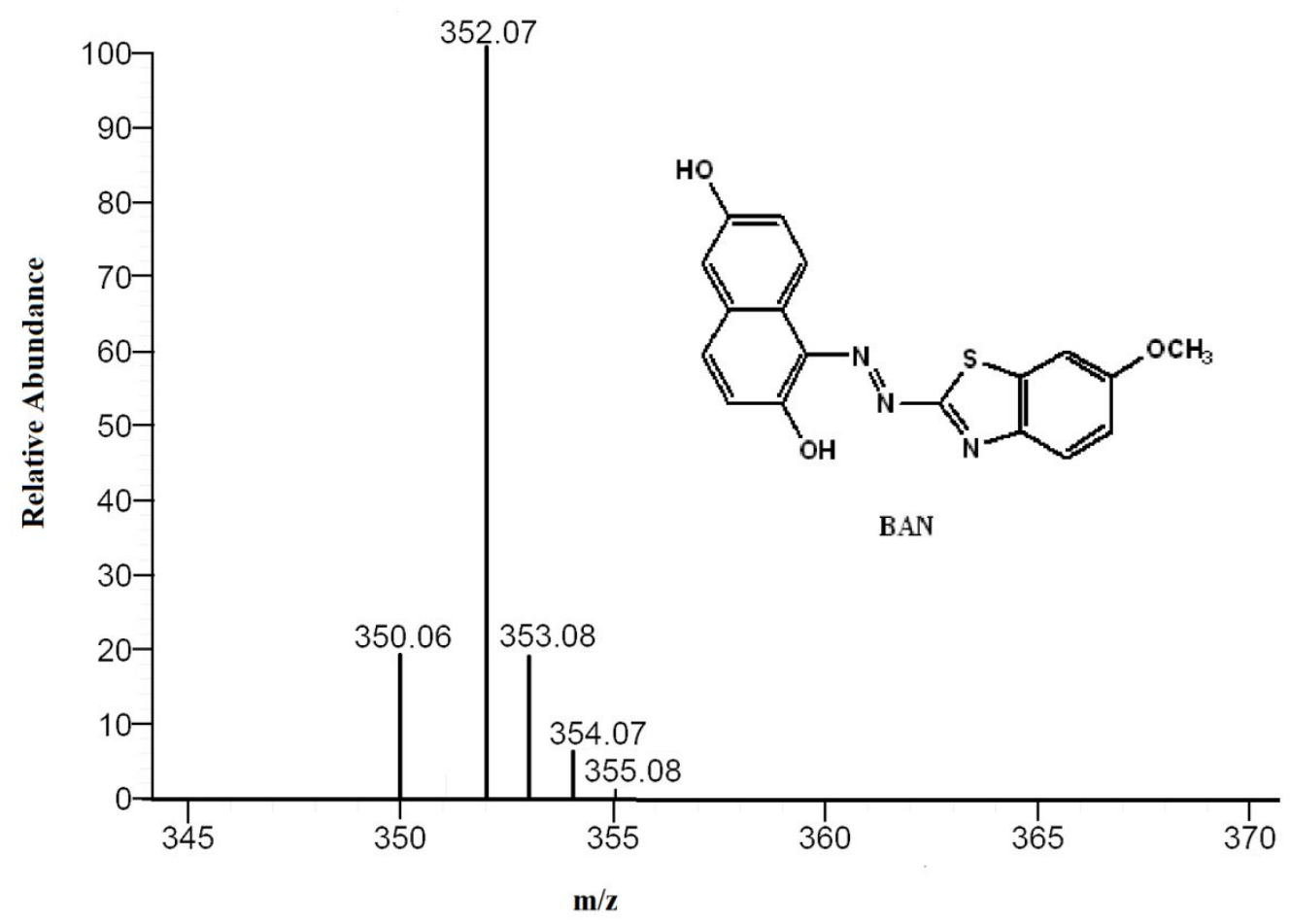

Fig. S5. Mass spectrometry of BAN. 


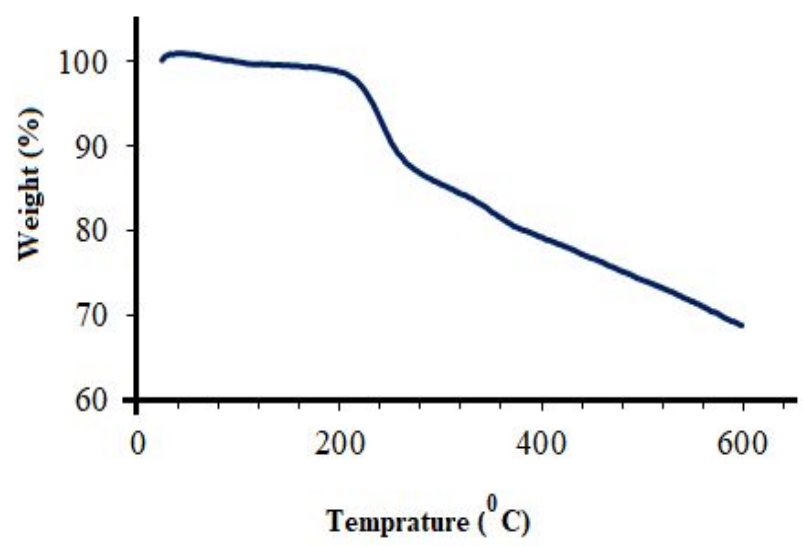

Fig. S6. TGA thermogram of BAN.

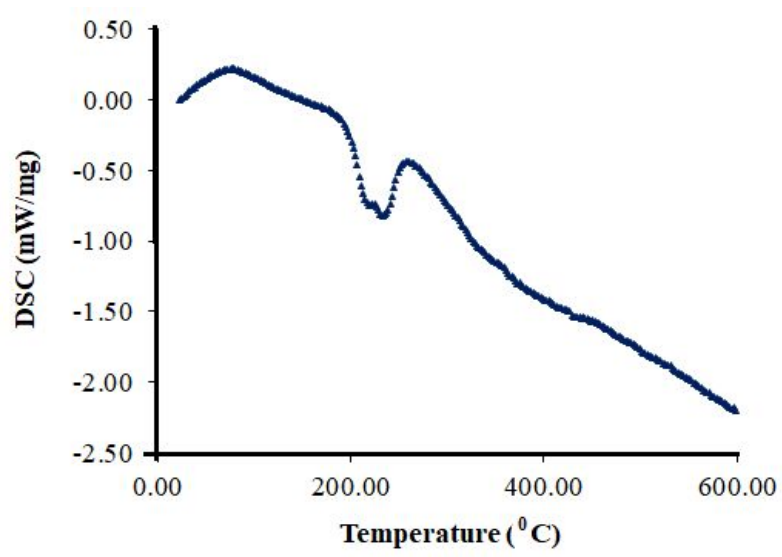

Fig. S7: DSC analysis of BAN. 


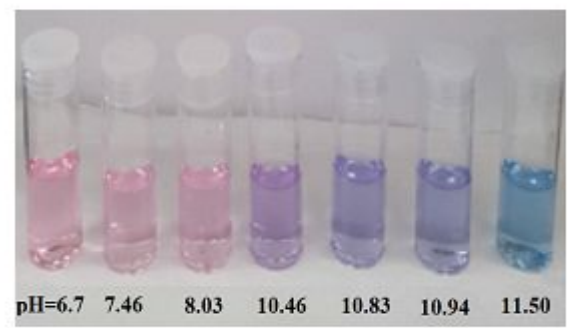

BAN colour in absence of $\mathrm{Hg}^{2+}$ ions

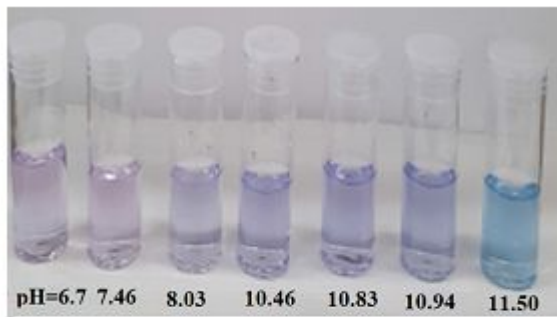

BAN colour in presence of $\mathrm{Hg}^{2+}$ ions
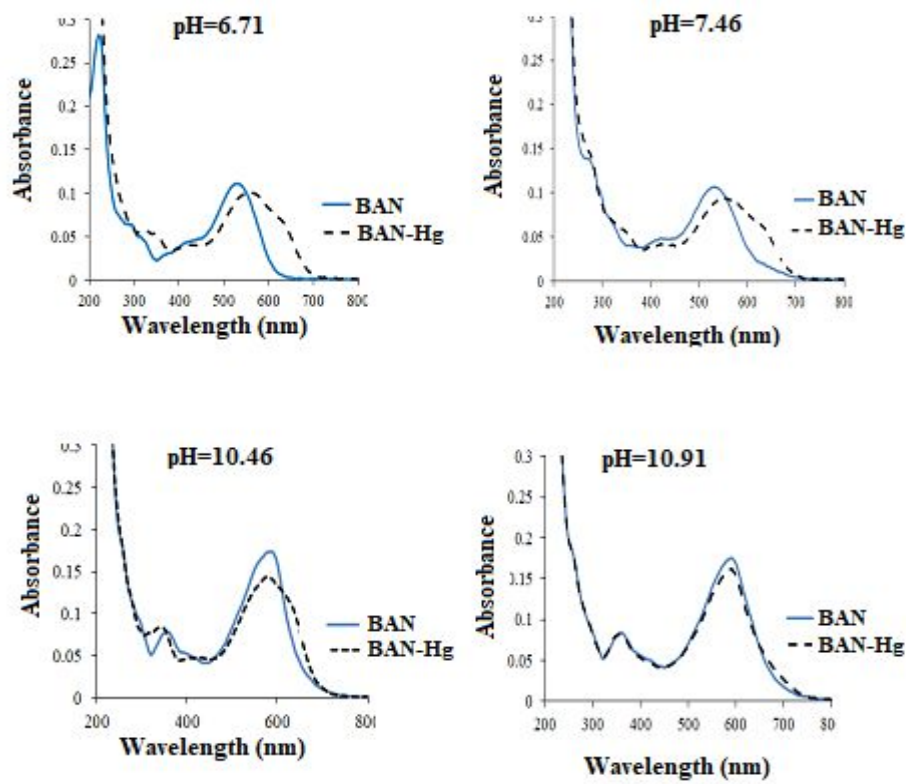
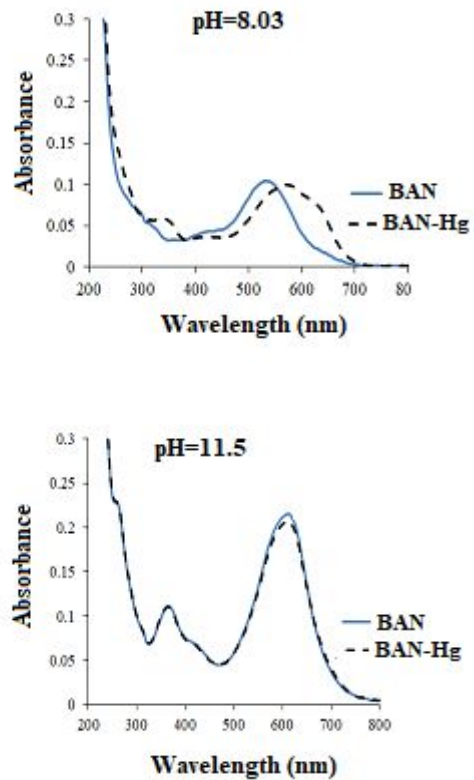

Fig. S8. Colour change and UV-VIS spectra of chemosensor BAN in the absence and presence of $\mathrm{Hg}^{2+}$ ions at different values. 


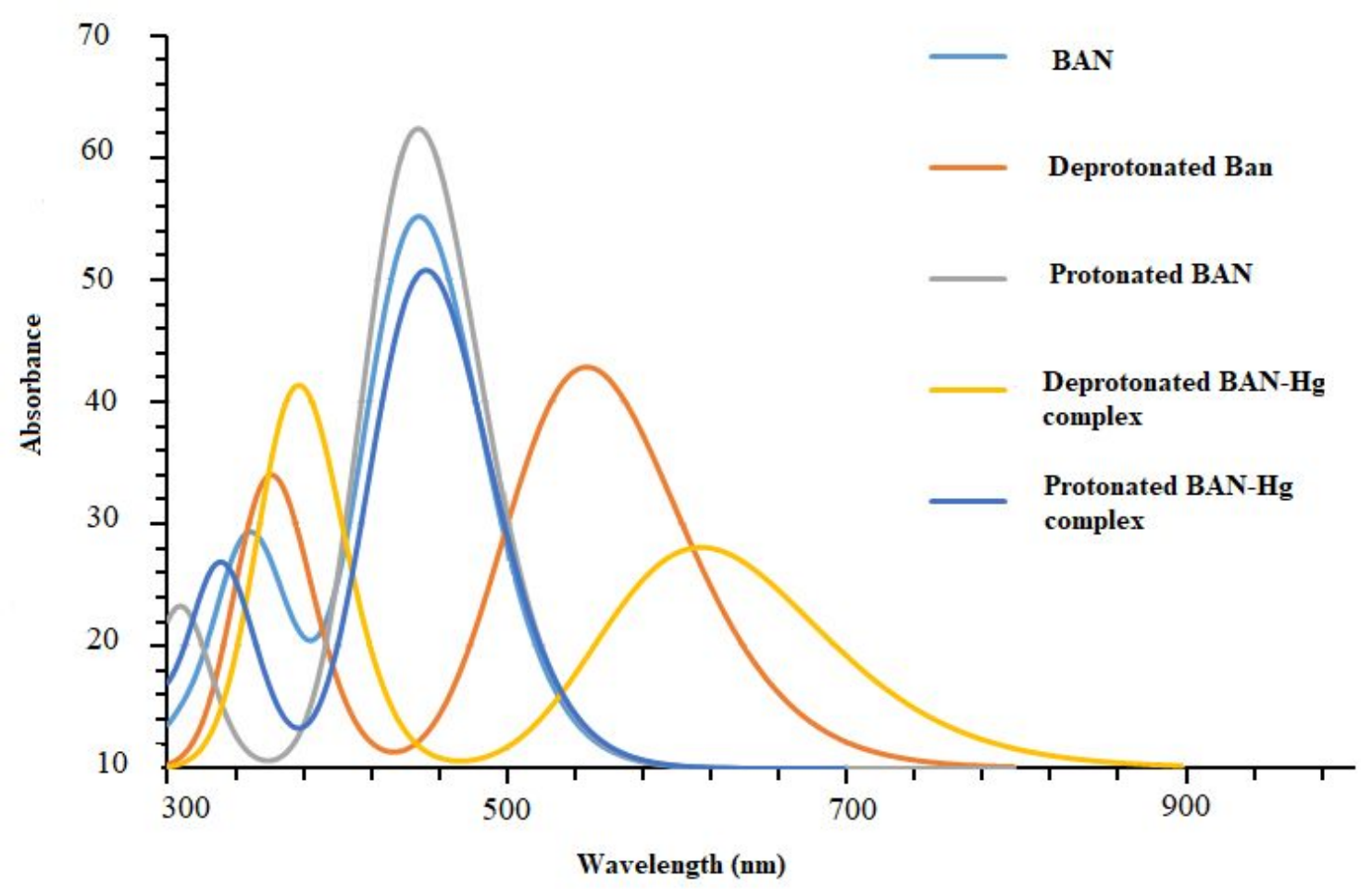

Fig. S9. Computed absorption spectra of BAN and deprotonated BAN (a Gaussian broadening of $0.25 \mathrm{eV}$ HWHM is applied).

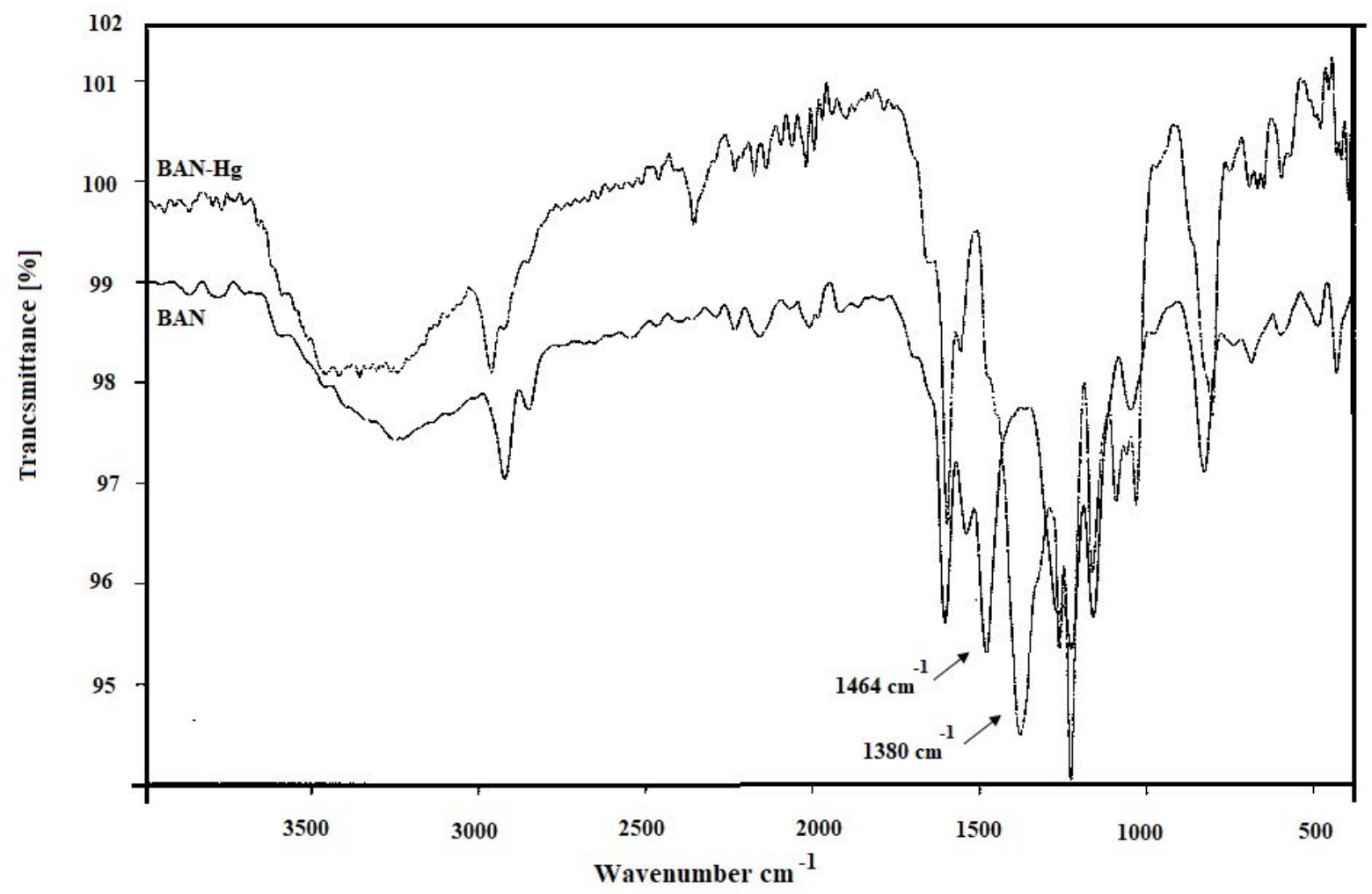

Fig. S10. FT-IR Spectra of BAN and BAN - $\mathrm{Hg}^{2+}$ complex. 

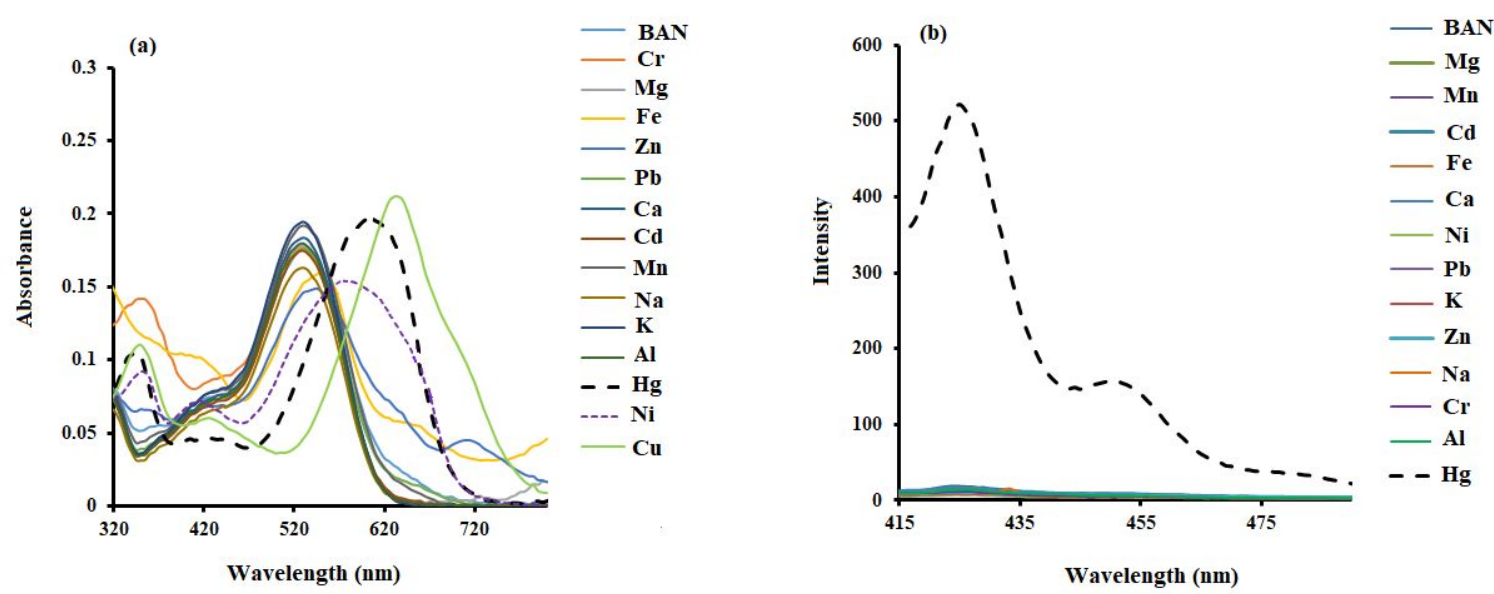

Fig. S11. (a) UV-Vis spectra of BAN $\left(1 \times 10^{-5} \mathrm{M}\right)$ after the addition of 13 metal ions $\left(5 \times 10^{-5} \mathrm{M}\right)$, (b) Fluorescence emission spectra of BAN $\left(1 \times 10^{-5} \mathrm{M}\right)$ after the addition 13 metal ions $\left(5 \times 10^{-5} \mathrm{M}\right)$.

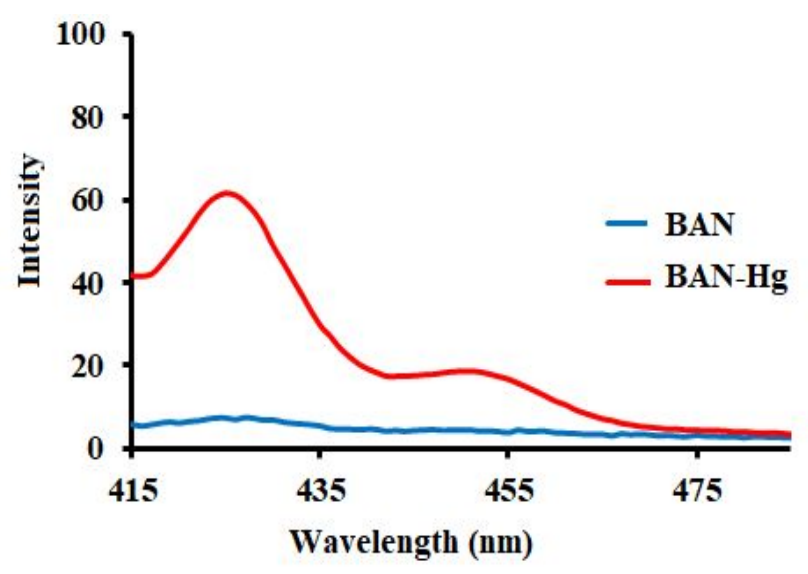

Fig. S12. Fluorescence emission spectra of BAN $\left(1 \times 10^{-7} \mathrm{M}\right)$ before and after interaction with blank and spiked tap water $\left(\mathrm{Hg}^{2+}\right.$ concentration $\left.=5 \times 10^{-8} \mathrm{M}\right)$ at $\mathrm{pH}$. The excitation wavelength was $\lambda_{\mathrm{ex}}=252 \mathrm{~nm}$. 


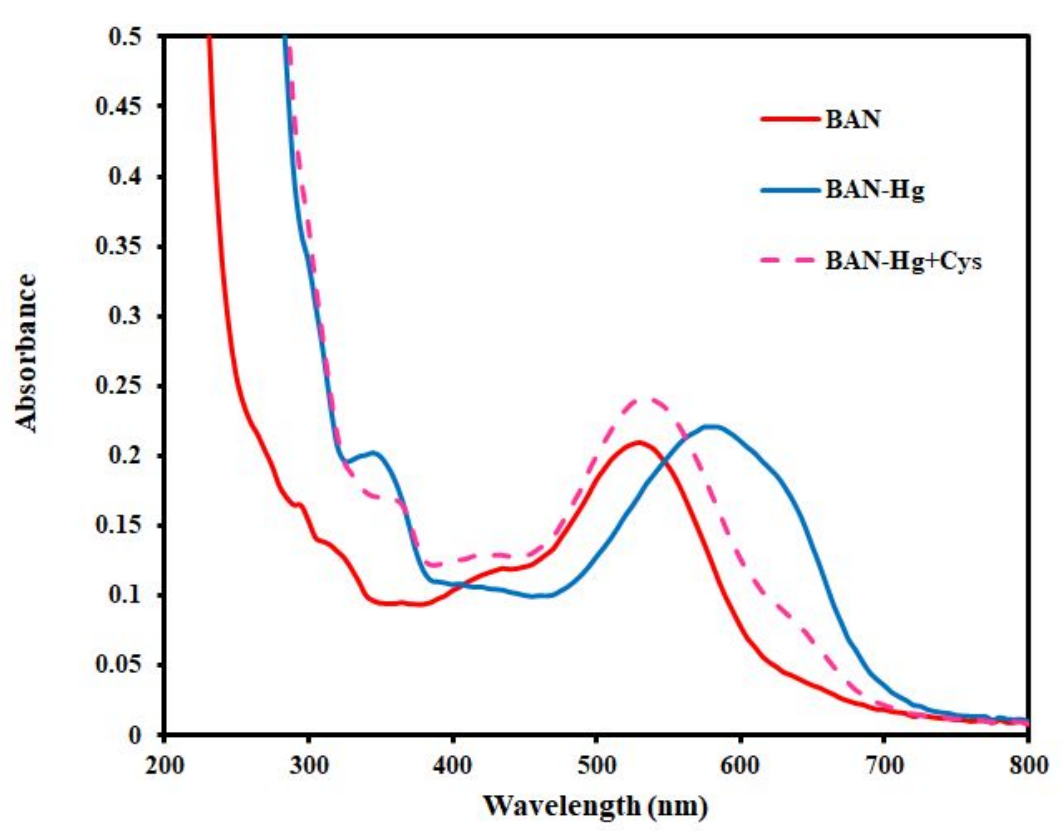

Fig. S13. The UV-Vis spectra of a) BAN dye $\left(5 \times 10^{-6} \mathrm{M}\right.$ in $\left.\mathrm{ACN}: \mathrm{H}_{2} \mathrm{O}, 1: 1 \mathrm{v} / \mathrm{v}\right)$, b) BAN- $\mathrm{Hg}^{2+}$ complex and c) The BAN- $\mathrm{Hg}^{2+}$ complex after the addition of cysteine.
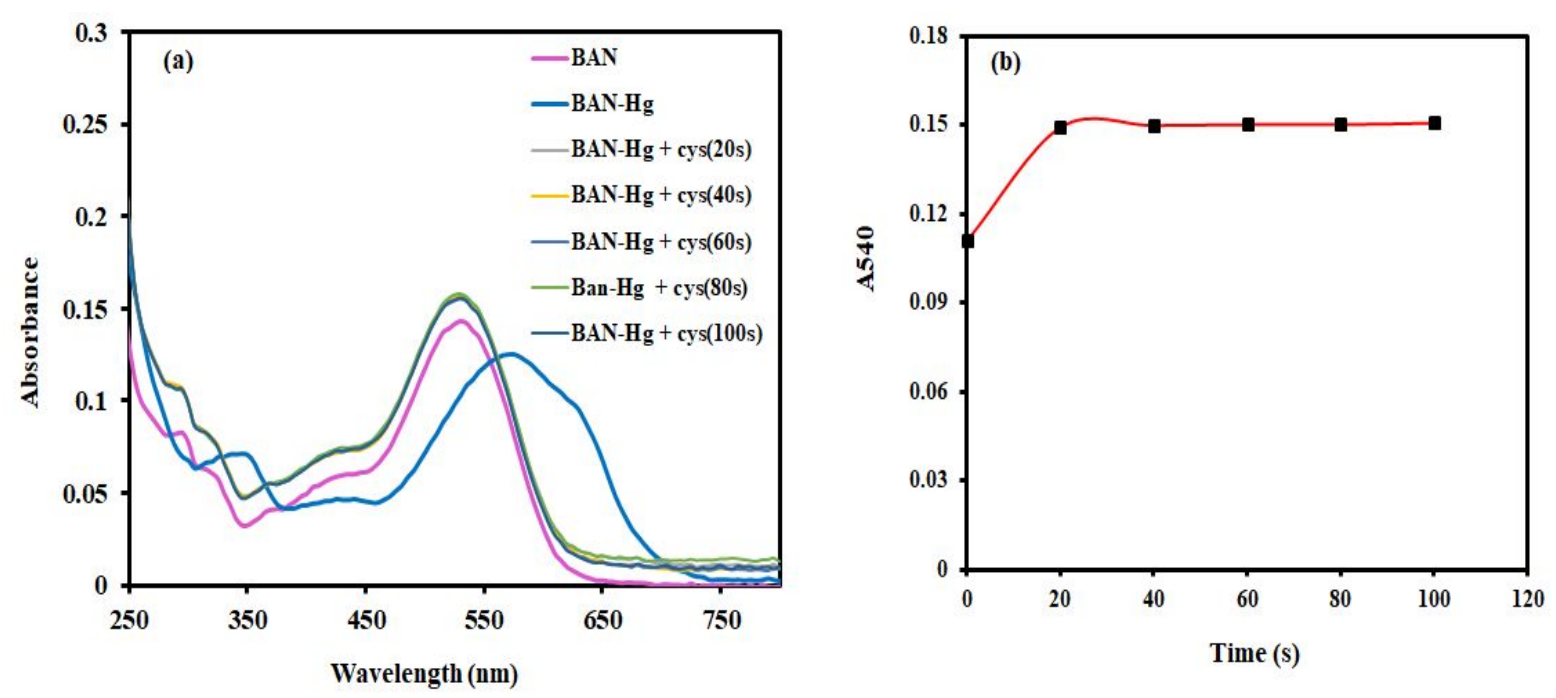

Fig. S14. (a) The UV-Vis spectra of BAN-Hg ${ }^{2+}$ complex $\left(5 \times 10^{-6} \mathrm{M}\right.$ in $\left.\mathrm{ACN}: \mathrm{H}_{2} \mathrm{O}, 1: 1 \mathrm{v} / \mathrm{v}\right)$ after addition of cysteine during $100 \mathrm{~s}$, (b) Plotted absorbance at $540 \mathrm{~nm}$ against time (s). 


\section{Determination of Quantum yield}

The luminescence quantum yield was measured using anthracene $\left(\phi_{\mathrm{f}}=0.27\right.$ in ethanol $)$ as a reference dye. Both the BAN compound and the reference were excited at the same wavelength $\left(\lambda_{\mathrm{ex}}=252 \mathrm{~nm}\right)$, maintaining nearly equal absorbance $(\sim 0.1)$, and the emission spectra were obtained at $425 \mathrm{~nm}$. The quantum yield is calculated according to the following equation:

$$
\emptyset_{S}=\emptyset_{R}\left[\frac{A_{S}}{A_{R}}\right]\left[\frac{A b s_{R}}{A b s_{S}}\right]\left[\frac{n_{S}^{2}}{n_{R}^{2}}\right]
$$

where $\mathrm{A}$ is the integrated intensity of the luminescence, Abs is absorbance at the excitation wavelength, $\mathrm{n}$ is the refractive index of the solvent and $\phi$ is fluorescence quantum yield. 
Table S1. Comparison of optical probes for $\mathrm{Hg}^{2+}$ ions.

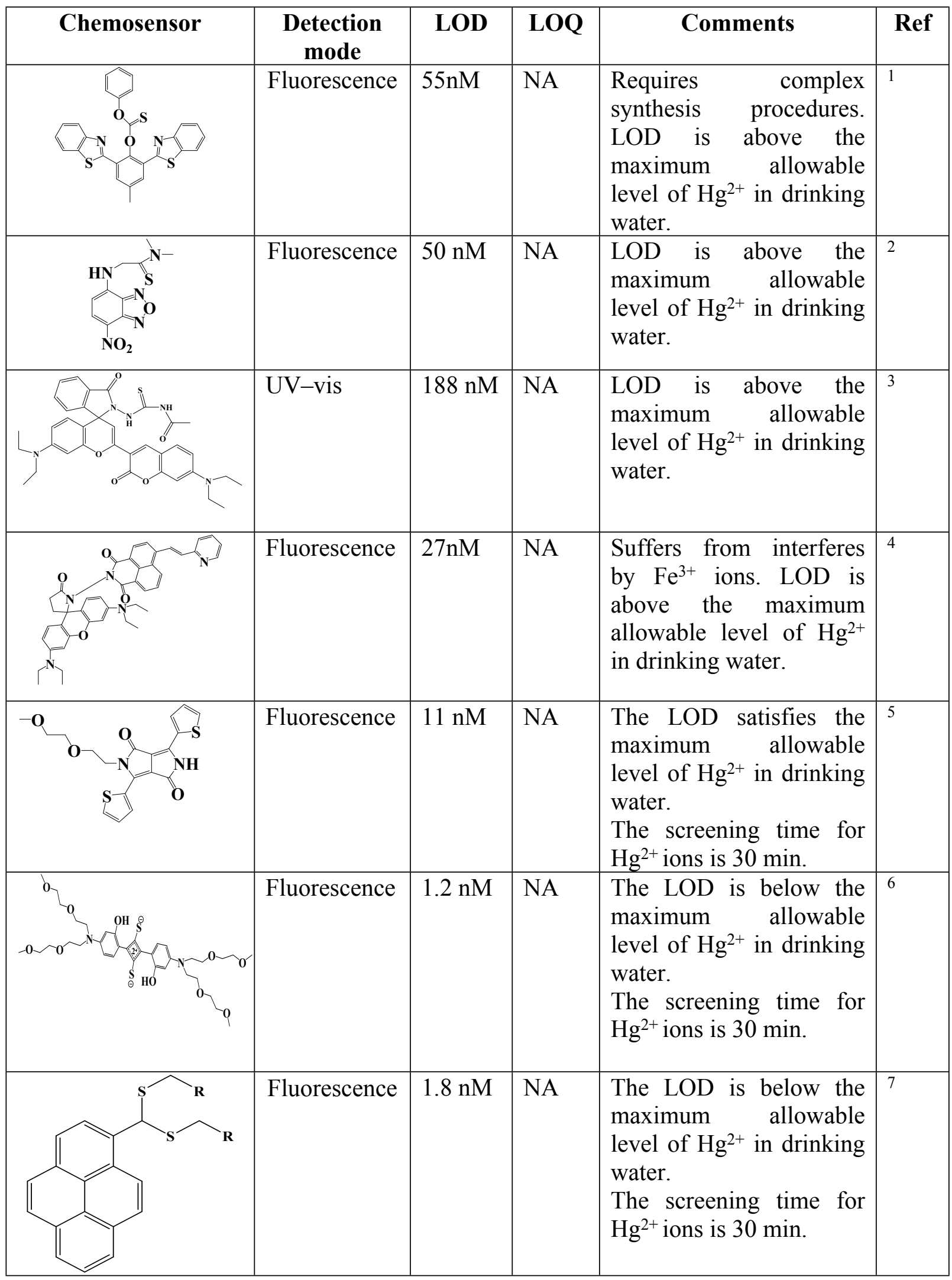


Table S1. Continued.

\begin{tabular}{|l|l|l|l|l|l|}
\hline mode & LOD & LOQ & \multicolumn{2}{|c|}{ Comments } & Ref \\
\hline Fetection & $150 \mathrm{nM}$ & $510 \mathrm{nM}$ & $\begin{array}{l}\text { The LOD is above } \\
\text { the maximum } \\
\text { allowable level of } \\
\mathrm{Hg}^{2+} \text { in drinking } \\
\text { water. }\end{array}$ & $\begin{array}{l}\text { The LOD is above } \\
\text { the maximum } \\
\text { allowable level of } \\
\text { Hg in drinking } \\
\text { water. }\end{array}$ \\
\hline
\end{tabular}

\section{References}

1 J. Xu, Z. Xu, Z. Wang, C. Liu, B. Zhu, X. Wang, K. Wang, J. Wang and G. Sang, Luminescence, 2018, 33, 219-224.

2 K. Wang, X. Mao, L. Cao, G. Lv, X. Dong, Y. He and Y. Wei, J. Fluoresc., 2017, 27, 1739-1745.

3 D. S. Lim, S. Y. Park, K. S. Hwang and S.-K. Chang, Tetrahedron Lett., 2018, 59, 1819-1822.

4 J. Liu and Y. Qian, J. Lumin., 2017, 187, 33-39.

$5 \quad$ K. Nie, B. Dong, H. Shi, Z. Liu and B. Liang, Anal. Chem., 2017, 89, 2928-2936.

6 G. Wang, W. Xu, H. Yang and N. Fu, Dyes Pigm, 2018, 157, 369-376.

7 Y. Gao, T. Ma, Z. Ou, W. Cai, G. Yang, Y. Li, M. Xu and Q. Li, Talanta, 2018, 178, 663-669.

8 B. K. Momidi, V. Tekuri and D. R. Trivedi, Inorg. Chem. Commun., 2016, 74, 1-5.

9 S.-L. Pan, K. Li, L.-L. Li, M.-Y. Li, L. Shi, Y.-H. Liu and X.-Q. Yu, Chem. Commun., 2018, 54, 49554958. 


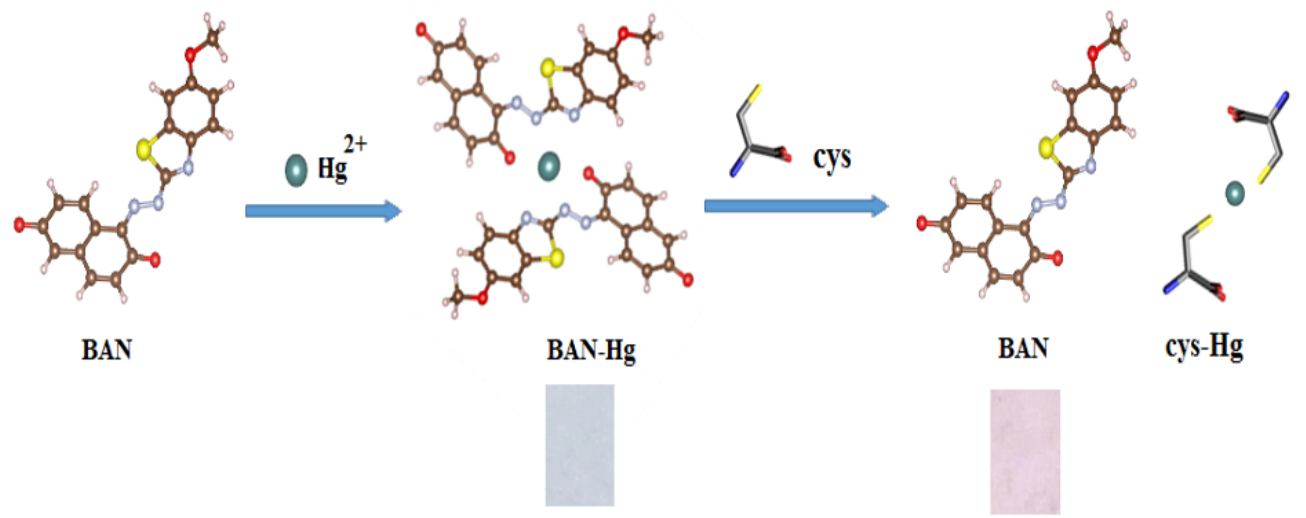

$250 \times 124 \mathrm{~mm}(96 \times 96 \mathrm{DPI})$ 